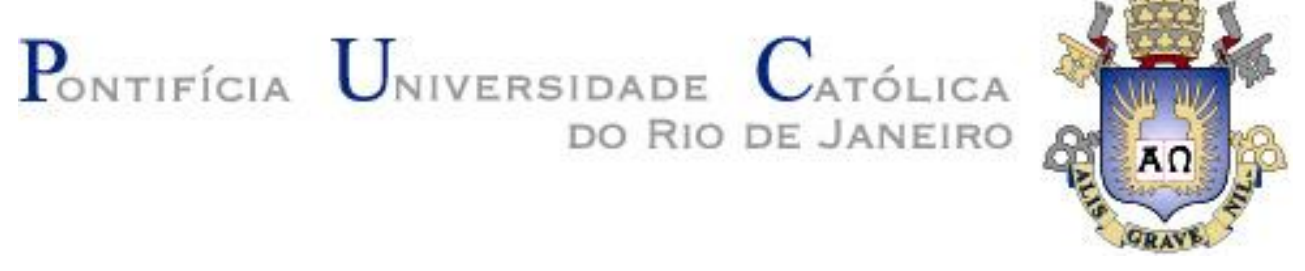

Luiz Fernando Perrotta da Rocha

\title{
“Como ganhar dinheiro na internet?": a Construção da Carreira do Empreendedor Digital
}

Dissertação de Mestrado

Dissertação apresentada como requisito parcial para obtenção do grau de Mestre pelo Programa de Pósgraduação em Administração de Empresas do Departamento de Administração da PUC-Rio.

Orientadora: Prof ${ }^{a}$. Ana Heloísa da Costa Lemos

Rio de Janeiro

Setembro de 2021 


\section{Luiz Fernando Perrotta da Rocha}

\section{“Como ganhar dinheiro na internet?”: a Construção da Carreira de Empreendedor Digital}

Dissertação apresentada como requisito parcial para obtenção do grau de Mestre pelo Programa de Pós-Graduação em Administração de Empresas da PUC-Rio. Aprovada pela Comissão Examinadora abaixo.

Profa. Ana Heloísa da Costa Lemos

Orientadora.

Departamento de Administração - PUC-Rio

Profa. Flávia de Souza Costa Neves Cavazotte

Departamento de Administração - PUC-Rio

Prof ${ }^{\text {a }}$ Tereza Cristina Batista de Lima

Universidade Federal do Ceará

Rio de Janeiro, 29 de setembro de 2021 
Todos os direitos reservados. É proibida a reprodução total ou parcial do trabalho sem autorização da universidade, do autor e do orientador.

\section{Luiz Fernando Perrotta da Rocha}

Engenheiro de Produção pelo CEFET-RJ (2012) e pós graduado em Gestão de Negócios pelo IBMEC-RJ (2014).

Ficha Catalográfica

Rocha, Luiz Fernando Perrotta da

"Como ganhar dinheiro na internet?" : a construção da carreira de empreendedor digital / Luiz Fernando Perrotta da Rocha ; orientadora: Ana Heloísa da Costa Lemos. - 2021.

84 f. ; $30 \mathrm{~cm}$

Dissertação (mestrado)-Pontifícia Universidade Católica do Rio de Janeiro, Departamento de Administração, 2021.

Inclui bibliografia

1. Administração - Teses. 2. Desenvolvimento de carreiras.

3. Empreendedorismo digital. 4. Novas carreiras. 5. Life design. I. Lemos, Ana Heloísa da Costa. II. Pontifícia Universidade Católica do Rio de Janeiro. Departamento de Administração. III. Título. 


\section{Agradecimentos}

À minha família, pelo apoio e incentivo à educação ao longo de toda minha vida.

À minha orientadora, Ana Heloísa Lemos, pela paciência e dedicação.

À CAPES e à PUC-Rio, pelo suporte.

O presente trabalho foi realizado com apoio da Coordenação de Aperfeiçoamento Pessoal de Nível Superior - Brasil (CAPES) - Código de Financiamento 001. 


\section{Resumo}

Rocha, Luiz Fernando Perrotta da; Lemos, Ana Heloísa da Costa. "Como ganhar dinheiro na internet?": a Construção da Carreira de Empreendedor Digital. Rio de Janeiro, ano 2021. 82p. Dissertação de Mestrado - Departamento de Administração, Pontifícia Universidade Católica do Rio de Janeiro.

Muitas pessoas têm buscado na internet uma forma de ganhar dinheiro. Dentre aqueles que tentam, há quem consiga ganhar a vida comercializando serviços e produtos digitais e construindo carreiras dedicadas a tal iniciativa: são os chamados empreendedores digitais. As trajetórias profissionais desses empreendedores ainda são pouco compreendidas, o que motivou a realização da presente dissertação que buscou entender a construção da carreira de empreendedor digital. Para tanto, a teoria do Life Design foi utilizada como principal lente conceitual para desvelar essas carreiras. Para alcançar o objetivo proposto foram entrevistados 13 empreendedores digitais. Os resultados obtidos indicam que aqueles que se autodenominam empreendedores digitais dedicam-se, sobretudo, ao marketing digital e constroem suas carreiras ratificando a retórica de que o empreendedorismo digital é um caminho viável para o enriquecimento, para conquistar flexibilidade de tempo, espaço e área de atuação, desde que se trabalhe com consistência, aprendendo constantemente e fazendo networking. Dentre as principais motivações para empreender online estão: insatisfação com trabalhos anteriores; ambição de ganhar mais dinheiro; desejo de empreender com baixos investimento e risco e; monetização de um hobby. Já os principais desafios são: falta de apoio da família e de amigos; preocupações com a saúde mental e física; dificuldades com o uso da tecnologia; medo de acreditar em promessas vazias e preocupações com ataques de ódio. No que diz respeito aos aspectos objetivos da construção da carreira, quatro momentos apareceram como importantes: pesquisar no google maneiras de ganhar dinheiro na internet; consumir conteúdo sobre marketing digital; realizar a 
primeira venda online e; participar em congressos ou eventos do setor. Constatou-se que, ao superarem as dificuldades e obterem conquistas, os empreendedores digitais legitimam suas escolhas de carreira.

\section{Palavras-chave}

Desenvolvimento de carreiras; Empreendedorismo Digital; Novas Carreiras; Life Design; 


\section{Abstract}

Rocha, Luiz Fernando Perrotta da; Lemos, Ana Heloísa da Costa (Advisor). "How to make money on the internet?": Constructing a Digital Entrepreneur's Career. Rio de Janeiro, ano 2021. 82p. Dissertação de Mestrado - Departamento de Administração, Pontifícia Universidade Católica do Rio de Janeiro.

Many people have searched the internet for a way to make money. Among those who try, there are those who manage to make a living selling digital services and products and building careers dedicated to such an initiative: they are called digital entrepreneurs. The professional trajectories of these entrepreneurs are still poorly understood, which motivated the completion of this dissertation, which sought to understand the construction of a digital entrepreneur career. Therefore, Life Design theory was used as the main conceptual lens to unveil these careers. To achieve the proposed objective, 13 digital entrepreneurs were interviewed. The results obtained indicate that those who call themselves digital entrepreneurs are dedicated, above all, to digital marketing and build their careers confirming the rhetoric that digital entrepreneurship is a viable path to enrichment, to achieve flexibility in time, space and area of performance, as long as one works consistently, constantly learning and networking. Among the main motivations to be a digital entrepreneur are dissatisfaction with previous work; ambition to earn more money; desire to undertake with low investment and risk and monetizing a hobby. The main challenges are lack of support from family and friends; mental and physical health concerns; difficulties with the use of technology; fear of believing empty promises and concerns about hate attacks on the internet. With regard to the objective aspects of career building, four moments appeared as important: searching google for ways to earn money on the internet; consume content about digital marketing; make the first online sale and participate in congresses or events in the sector. It was found that, by overcoming difficulties and achieving goals, digital entrepreneurs 
legitimize their career choices.

\section{Keywords}

Career development; Digital Entrepreneurship; New Careers; Life Design; 


\section{Sumário}

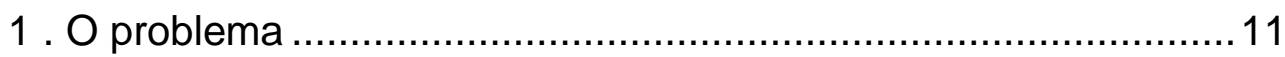

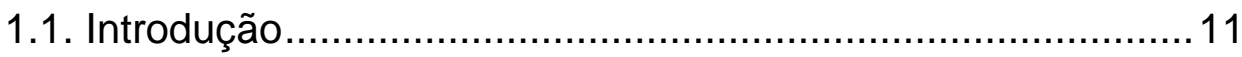

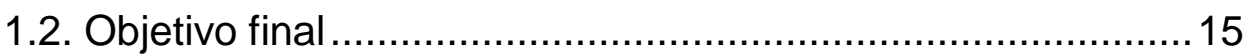

1.3. Relevância do estudo .........................................................15

1.4. Delimitações do estudo ....................................................16

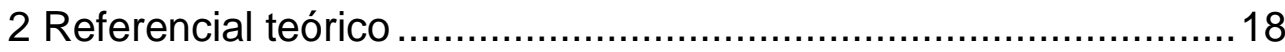

2.1. Empreendedorismo Digital .................................................18

2.1.1. Conceituando o empreendedorismo ...............................18

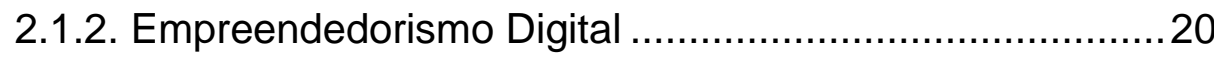

2.1.3. Habilidades do empreendedor digital .............................23

2.1.4. Empreendedorismo Digital e Marketing de Afiliados .......26

2.2. Desenvolvimento de Carreira ..............................................28

2.2.1. Perspectivas modernistas de carreira ...........................28

2.2.2. Perspectivas pós-modernistas de carreira ......................32

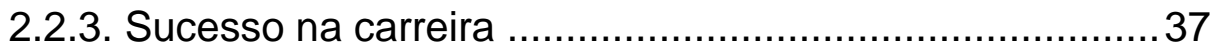

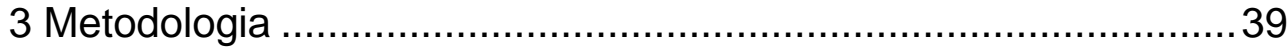

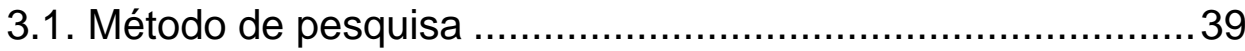

3.2. Seleção dos sujeitos ........................................................... 40

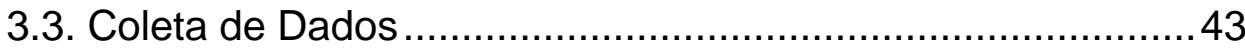

3.4. Tratamento dos dados ........................................................ 43

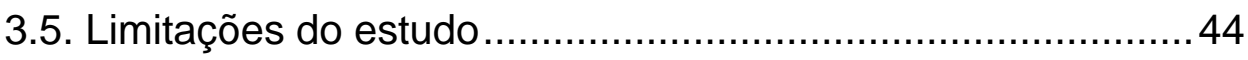

4 Análise e Discussão dos Resultados ............................................45

4.1. Análise do perfil e nichos de atuação dos entrevistados ....... 45

4.2. Marcos objetivos da carreira dos empreendedores digitais... 48 
4.2.1. Pesquisa sobre "como ganhar dinheiro na internet" 48

4.2.2. Ser cliente digital antes de se tornar empreendedor digital

4.2.3. Realização da primeira venda ......................................51

4.2.4. Participação em congressos ou eventos presenciais ......52

4.3. Motivações para a carreira de empreendedor digital .............53

4.3.1. Insatisfação com o(s) trabalho(s) anterior (es) ..............54

4.3.2. Ambição em ganhar dinheiro "sem sair de casa" ............55

4.3.3. Desejo de empreender com baixos risco e investimentos iniciais .56

4.3.4. Monetização de um hobby .....................................56

4.3.5. Sucesso na carreira de empreendedor digital ...............58

4.4. Desafios e barreiras ao empreendedorismo digital..............60

4.4.1. Dificuldades em usar a tecnologia...............................60

4.4.2. Comprometimento da saúde ....................................61

4.4.3. Preocupações com ataques de haters e de hackers.......62

4.4.4. Falta de apoio e críticas da família e dos amigos............63

4.4.5. Preocupação com charlatanismo e enganações .............64

4.5. A construção identitária da carreira do empreendedor digital 65

4.5.1. O Empreendedor digital como pessoa que prescinde da educação formal 67

4.5.2. Empreendedor digital como patrão de si mesmo e dono do próprio tempo. 69

4.5.3. Empreendedor digital como trabalhador incansável e resiliente 69

4.5.4. Empreendedor digital como detentor de altos retornos financeiros .71

4.5.5. Empreendedor digital como o profissional do futuro .......71 
4.5.6. Empreendedor digital como profissional do networking ..73

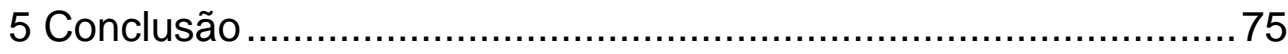

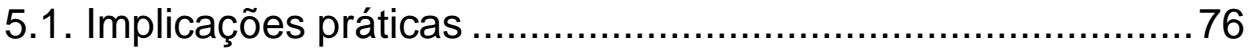

5.2. Sugestões de estudos futuros ........................................... 77

6 Referências Bibliográficas........................................................ 


\section{Lista de Tabelas}

Tabela 1 - Habilidades do empreendedor digital .........................25

Tabela 2 - Desenvolvimento de carreira: retórica e repertórios .......32

Tabela 3 - Perfil dos entrevistados ......................................... 42

Tabela 4 - Nicho de atuação dos entrevistados no momento da entrevista 


\section{O problema}

Esse capítulo volta-se à apresentação do tema de estudo da presente dissertação. Assim, apresentam-se o problema que suscitou a proposta de investigação e os respectivos objetivos de pesquisa. Na sequência, são indicadas a relevância e a delimitação do estudo.

\subsection{Introdução}

As inovações tecnológicas, organizacionais e de mercado têm impulsionado profundas transformações no mundo do trabalho (WRIGHT et al.,2010). De um lado diversas carreiras ditas "inovadoras" estão sendo criadas para acompanharem o ritmo das mudanças, do outro lado, transformações estruturais nas relações de trabalho também têm sido observadas. Como consequência dessas transformações, o empreendedorismo tem sido a alternativa para a geração de emprego e renda. (WRIGHT et al.,2010; DA SILVA \& SILVA, 2019).

Da Silva e Silva (2019) mostraram que o Brasil, nos últimos anos, apresentou um crescimento significativo no que tange ao empreendedorismo por oportunidade e que 0 desenvolvimento da economia brasileira é em sua maioria gerado pelas micro e pequenas empresas, que ao iniciarem as atividades do empreendedorismo, contribuem para a geração de emprego, refletindo positivamente na economia.

Alguns autores, no entanto, questionam o discurso excessivamente positivo que associa apenas virtudes ao empreendedorismo. Costa et al. (2012), por exemplo, apontam que o discurso que valoriza o empreendedorismo apresenta três problemas: primeiro, é uma retórica que corrobora a ordem econômica mundial atual como natural, contra a qual nada se pode fazer, a não ser a ela aderir. Segundo, existe implícita uma positividade atribuída ao lucro e à lógica produtivista racional que tem por objetivo predominantemente o crescimento econômico e, em terceiro lugar, o discurso de que o empreendedor seria um "herói global", generalizando modelos emblemáticos e contribuindo para uma imagem objetificada de como se deve viver a vida, o que aprisionaria o ser humano nessa busca incansável por resultados econômicos (COSTA et al., 2012).

A despeito do debate existente sobre a valorização da atividade empreendedora, vale destacar que a recente expansão de tecnologias digitais, tais como nuvem, mídias 
sociais, internet das coisas, big data, smartphones, realidade aumentada etc são inovações que transformam a natureza dos processos e resultados relacionados ao empreendedorismo (NAMBISAN, 2017). Essa revolução digital sem precedentes transformou o significado e as formas de empreender em todo o mundo (GIONES \& BREM, 2017). Segundo a Accenture (2014), a maioria dos empreendedores e microempreendedores vem abraçando essas inovações tecnológicas com entusiasmo, com vistas a melhor posicionar seus negócios. Resultante da interseção entre tecnologias digitais e empreendedorismo, o empreendedorismo digital surge como um novo espaço de atuação profissional e um rico campo para pesquisa (NAMBISAN, 2017). Em outras palavras, "o empreendedorismo digital leva toda a complexidade e fragmentação do empreendedorismo um passo adiante" (ZAHEER; BREYER; DUMAY, 2019, p. 13).

Contudo, em uma ampla revisão da literatura sobre empreendedorismo digital, Zaheer, Breyer, Dumay (2019), concluíram que a pesquisa sobre empreendedorismo digital tem sido fragmentada, divergente e lenta para responder à prática. As pesquisas sobre o tema ainda são incipientes na literatura sobre negócios digitais e respondem por menos de $10 \%$ do impacto geral do setor, apesar da tendência de aumento nos últimos anos (ZAHEER; BREYER; DUMAY, 2019). Essa visão é corroborada por outra revisão de literatura sobre empreendedorismo digital, elaborada por Anim-Yeboah et al. (2020), na qual os autores não só apontam que existem poucos estudos sobre o tema, como também mostram que os estudos existentes enfatizam principalmente questões relacionadas à tecnologia, sendo poucos os estudos que focam na figura do empreendedor digital. Em outros termos, apesar do crescimento substancial dos negócios online, ainda faltam dados sobre empreendedores digitais (DY et al., 2017).

Como pouco se sabe sobre a diversidade e distribuição da atividade (DY et al., 2017), não existe uma definição clara do que é ser empreendedor digital (NAMBISAN, 2017). Além de possuir diferentes definições, a terminologia 'empreendedorismo digital' não é usada em todos os artigos da mesma maneira (KRAUS et al., 2018). Dheeryia (2009), por exemplo, usa o termo 'empreendedorismo online' para definir qualquer empreendimento conduzido exclusivamente na rede mundial de internet World Wide Web (www) e essa definição poderia ser usada para definir o empreendedorismo digital.

Outro fator que contribui para a fragmentação das pesquisas sobre o tema reside no fato de que existe ampla heterogeneidade entre as empresas digitais: algumas são fortemente baseadas em tecnologia, tais como as de web design e e-commerce, enquanto outras podem ser classificadas como digitais simplesmente porque 0 marketing e as comunicações ocorrem predominantemente online (DY et al., 2017). 
Entretanto, existem alguns consensos nos estudos sobre empreendedorismo digital. Um exemplo disso é que vários autores concordam que o empreendedorismo digital difere do tradicional pois, em geral, começar um novo negócio ou lançar um novo produto no modelo tradicional é caro e arriscado para iniciantes e, em contrapartida, no mundo digital, não apenas as barreiras para começar algo novo são reduzidas, mas uma variedade de caminhos para um empreendimento bem-sucedido é oferecida (KUESTER et al., 2018; GUTHRIE, 2014; ACCENTURE, 2014).

Anim-Yeboah et al. (2020, p.200) também constataram que "pesquisas futuras deveriam considerar os drivers $e$ as motivações do empreendedor para 0 empreendedorismo digital'.

Em um cenário onde "o desemprego entre jovens atingiu um nível crítico para potencialmente se tornar um bomba-relógio política" (ACCENTURE, 2014, p. 6), o retrato da internet como um facilitador do potencial empreendedor, dada a sua acessibilidade (KUESTER et al., 2018; GUTHRIE, 2014; ACCENTURE, 2014), aliada à retórica de fácil geração de renda (DY et al., 2017) tem levado um número crescente de pessoas a empreender na internet, tanto no Brasil como no mundo. Como as pessoas estão cada vez mais motivadas pelos seus objetivos próprios do que pelas perspectivas de trilhar uma carreira organizacional (SULLIVAN e BARUCH, 2009), o empreendedorismo digital representa uma oportunidade real de carreira para aqueles com experiência ou talento em um determinado campo (GUTHRIE, 2014). A constatação do surgimento dessas carreiras, construídas no ambiente digital, contrasta com a escassez de pesquisas capazes de dar conta do fenômeno e de explicitar como tais carreiras vêm sendo construídas e se desenvolvendo. Essa constatação motivou a realização da presente dissertação que buscou entender como empreendedores vem construindo suas carreiras.

Para abordar a questão da carreira de empreendedor digital buscou-se referências na literatura sobre carreira e desenvolvimento de carreira. Neste campo, há farta literatura acadêmica: desde o trabalho de Donald Super (1957) até os dias de hoje, muito se pesquisa sobre o desenvolvimento de carreiras. Entretanto, por muitos anos, a academia enfatizou a carreira confinada ao ambiente tradicional das organizações estruturadas (SULLIVAN E BARUCH, 2009). Somente depois dos anos 90 é que a academia começou a focar nas carreiras trilhadas fora das organizações (SULLIVAN E BARUCH, 2009). A partir daí, vários estudos sobre carreira passaram a enfatizar as competências, habilidades e crenças que um indivíduo precisaria desenvolver para seguir uma trajetória de carreira bem-sucedida. É o caso das teorias sobre carreira proteana (que aborda a capacidade das pessoas permanecerem resilientes e adaptáveis em suas trajetórias para lidar com o efeito de novas tecnologias e novos 
conceitos do trabalho) (HALL, 1996); carreira sem fronteiras (trajetória de carreira livre de acordos tradicionais com organizações) (ARTHUR, 1994); carreira caleidoscópica (carreira criada em seus próprios termos e trajetória definida pelos próprios valores, escolhas e parâmetros do indivíduo) (MAINIERO \& SULLIVAN, 2005); carreira portfolio (trajetória de carreira baseada em ser contratado por habilidades específicas em vários contextos, mas também acordos autônomos) (KOOIJ e BOON, 2018), dentre outras.

Todos esses novos formatos de carreira põem demasiada ênfase na trajetória (SAVICKAS, 2012) e visam ensinar ao indivíduo a construir seu caminho. Entretanto, dada a imprevisibilidade de um mundo em constante evolução tecnológica e com caminhos incertos, uma alternativa, ao se pensar na carreira, é, ao invés de focar na trajetória, pensar no veículo. Para Savickas (2010), o veículo que leva um indivíduo de uma carreira a outra, incluindo novas carreiras, é a história que ele conta sobre si mesmo, sua autobiografia.

Sendo assim, Savickas (2010) propõe a substituição de conceitos prevalecentes, sustentados pelo positivismo lógico, por constructos pós-modernos, baseados no construcionismo social. Sob essa perspectiva, os indivíduos elaboram ou mudam suas histórias de maneira que clarificam as escolhas e estimulam ações transformadoras para fazerem transições de vida (SAVICKAS, 2015). Em outras palavras, no nível individual, face à uma transição de vida que pode ser uma mudança de emprego, demissão, aposentadoria, iniciativa empreendedora ou qualquer outro evento disruptivo de carreira, as pessoas podem se perguntar como e porque aquilo aconteceu (BUJOLD, 2004). É comum que elas sintam a necessidade de organizar uma série de fatos e eventos em uma narrativa coerente (BUJOLD, 2004). Ou seja, a narrativa da carreira é uma maneira de construção identitária. Não é que a identidade seja algo instável, mas ter uma identidade implica estar continuamente trabalhando uma herança de gerações e fatos passados e construindo o próprio lugar (BUJOLD, 2004).

Blustein et al. (2004) dizem que as narrativas têm desempenhado um papel muito significativo na compreensão das relações de trabalho, espaços de trabalho, bem como de novas ideias. Assim sendo, haja vista a necessidade de se entender as novas carreiras que surgem em ambientes digitais, cujas relações se dão em um cenário dinâmico, considerou-se que o uso de metodologias qualitativas que levem em consideração as narrativas e histórias de profissionais que atuam nessas áreas possam ajudar na compreensão da carreira do empreendedor digital.

Nesse sentido, a teoria de Savickas conhecida como Life Design pode contribuir para a compreensão de novas carreiras em ambientes dinâmicos. A princípio, tal teoria visa ajudar indivíduos a fazerem escolhas de carreira e a aceitarem as mudanças através de uma intervenção na narrativa que os fazem revisar e elaborar uma nova 
identidade psicossocial (CARDOSO; SAVICKAS; GONÇALVES; 2019) porém, apesar de ser uma teoria que busca ensinar um método de aconselhamento que ajude psicólogos vocacionais e conselheiros de carreira a atuarem junto a seus clientes, ela também pode ajudar pesquisadores a entender como os indivíduos forjam suas identidades psicossociais após redefinirem suas escolhas de carreiras. A prática de interpretações de narrativas de carreira é um elemento chave nas pesquisas sobre carreira (YOUNG E COLLIN, 1992).

Por entender a carreira como uma narrativa que os indivíduos contam sobre os projetos que constroem em suas vidas (SAVICKAS, 2002), esse estudo visou, por meio de entrevistas em profundidade com empreendedores digitais, entender como as carreiras de empreendedores digitais vêm sendo constituídas objetiva e subjetivamente.

\subsection{Objetivo final}

Este trabalho visa a entender como a carreira de empreendedor digital é construída por aqueles que se dedicam a tal atividade.

Objetivos intermediários:

a) Entender de que forma atua o empreendedor digital;

b) Identificar marcos objetivos que fazem o empreendedor digital seguir nesta carreira;

c) Entender o que motivou os empreendedores digitais a seguirem esta trajetória;

d) Entender quais os desafios e barreiras os empreendedores enfrentam em suas carreiras;

e) Entender como os empreendedores digitais formam sua autoidentidade profissional;

\subsection{Relevância do estudo}

As pesquisas sobre empreendedorismo digital estão fragmentadas e várias delas divergem do que acontece na prática (ZAHEER; BREYER; DUMAY, 2019). Ainda, a maioria das pesquisas foca nas tecnologias por trás do empreendedorismo digital e poucas enfatizam a figura do empreendedor digital, em si (ANIM-YEBOAH et al. 2020). Soma-se a isso o fato de o termo 'empreendedorismo digital' não ter uma definição clara (NAMBISAN, 2017), o que leva pesquisadores, por vezes, a empregarem termos 
equivalentes, como empreendedorismo de internet ou empreendedorismo online (GUTHRIE, 2014; DHEERYIA 2009). Assim, é fundamental pesquisas que visam aclarar a carreira dos empreendedores digitais individuais.

Outro fator que contribui para a relevância deste estudo é o fato de que a pandemia do coronavírus (Covid-19) acelerou a tendência de digitalização, que já vinha crescendo, a se solidificar (BARBOSA, 2020). Segundo Barbosa (2020, p. 50), existe uma "parcela da população que não tinha hábito de digitalização e agora está sendo forçada ao uso e continuará a fazê-lo." Portanto, pesquisas que contribuam para o entendimento do cenário profissional digital são fundamentais.

Além disso, no que tange aos estudos sobre carreiras, a academia enfatizou, por muito tempo, a carreira confinada ao ambiente tradicional das organizações estruturadas (SULLIVAN E BARUCH, 2009), sendo necessário o desenvolvimento de estudos que visam entender objetivamente e subjetivamente as novas carreiras digitais individuais, como a do empreendedor digital.

\subsection{Delimitações do estudo}

Devido à ampla gama de pesquisas no âmbito do empreendedorismo digital, a compreensão do conceito é difusa e aberta a interpretações divergentes (ANIMYEBOAH et al., 2020). Muitos termos têm sido usados para descrever negócios criados na internet, como por exemplo empreendedorismo online, infoempreendedorismo, eempreendedorismo, empreendedorismo de internet e empreendedorismo digital (GUTHRIE, 2014). Além disso, existem negócios que operam $100 \%$ na internet e outros que, embora realizem suas transações na internet, possuem estoque, transporte e entrega de produtos físicos (GUTHRIE, 2014). Este estudo considera apenas os negócios digitais que operam com produtos $100 \%$ digitais, isto é, produtos feitos de bytes e sem nenhuma operação física. Sendo assim, não inclui negócios que envolvem produtos e operações físicas.

Ainda, por vezes, o termo 'empreendedorismo digital' é usado na literatura para descrever os processos que grandes corporações atravessam ao implementar tecnologias digitais em suas operações multinacionais. Esse uso do termo 'empreendedorismo digital' é bem diferente do que é usado neste estudo, que considera o poder de agência de um único empreendedor digital criando seu negócio na internet.

Outro ponto a ser levado em consideração está no fato de outras carreiras digitais estarem surgindo nos últimos anos, como é o caso dos youtubers e influenciadores digitais, por exemplo. Como não há uma definição clara do que seja o empreendedor digital (NAMBISAN, 2017), alguns estudos podem considerar qualquer carreira digital 
como sendo uma iniciativa empreendedora. Contudo, este estudo considera como empreendedor digital aquele que vende produtos ou serviços digitais por meio de redes eletrônicas (GUTHRIE, 2014). 


\section{Referencial teórico}

O presente capítulo, que apresenta o referencial teórico do trabalho, está estruturado em dois tópicos. O primeiro conceitua o empreendedorismo digital e como este se diferencia do empreendedorismo tradicional, além de explicações sobre marketing de afiliados e outros conhecimentos e habilidades ligadas ao empreendedorismo digital. O segundo tópico aborda alguns conceitos sobre carreira e desenvolvimento de carreira, sendo também explicada a visão epistemológica que orientou a pesquisa.

\subsection{Empreendedorismo Digital}

Neste tópico, antes de entrar nos principais conceitos e debate sobre empreendedorismo digital, o empreendedorismo tradicional será conceituado. Em seguida, serão apresentadas as habilidades específicas dos empreendedores digitais e, por último, será mostrado como as mudanças ocasionadas pelo chamado marketing de afiliados influenciaram o empreendedorismo digital.

\subsubsection{Conceituando o empreendedorismo}

Dentro do cenário econômico atual de globalização e alta competitividade, a atividade empreendedora tem se mostrado como uma das mais importantes forças impulsionadoras e estimuladoras de mudanças econômicas e sociais (NASSIF et al, 2009).

Entretanto, a definição de empreendedor possui diferentes interpretações, segundo Filion (1999), porque dependendo da área de estudos, o empreendedor pode ser compreendido de diferentes maneiras. Na área de Economia, por exemplo, a palavra empreendedor é associada com um agente responsável pela inovação e criação de novos negócios, tendo seus primeiros estudos se originado das pesquisas de Joseph Schumpeter em 1934.

Já para as áreas de Sociologia e Psicologia, o termo empreendedor está associado ao comportamento humano e, por consequência, há maior ênfase sobre os 
aspectos de criatividade e intuição dos indivíduos, com base nas pesquisas de David McClelland em 1961 ou Albert Shapero em 1975.

Segundo a visão de Filion (1999) o empreendedor é um indivíduo criativo que busca alcançar metas com objetividade, além de possuir uma capacidade aprimorada de percepção do ambiente para detectar oportunidades. Para Drucker (1987), o empreendedor é aquele que sempre está buscando a mudança, reagindo a ela e explorando-a como sendo uma oportunidade.

O empreendedor está relacionado às pessoas que possuem a inclinação para correr riscos, sejam os riscos financeiros, pelo investimento do capital ou outros tipos de riscos e desafios, mesmo até o risco de fracassar (FILION, 1999). Ainda, o empreendedor costuma ser apontado como alguém que tem iniciativa, é dinâmico e acaba por ter influência para a economia, pois ele costuma criar negócios ou inovar para obter ganhos financeiros, ou para melhorar a aplicação de seus recursos (WRIGHT et al., 2010).

Aliás, a ênfase nas características individuais do empreendedor originou o conceito de intra-empreendedorismo, um neologismo que trata sobre o estudo do empreendedorismo dentro das organizações (FILION, 1999). Esse conceito tem sido utilizado para engajar funcionários e parceiros, já que, em geral, as características individuais de um empreendedor são liderança, disposição ema assumir riscos, iniciativa, saber aproveitar oportunidades de mercado e saber gerenciar recursos (CAMARGO, 2010).

Na visão de Dolabela (2008), o empreendedor é aquele que tem uma visão de futuro, que consegue enxergar melhor o mercado, com isso ele adquire prática, e consegue criar diferenciais competitivos. Já para Camargo (2010, p. 43) o "empreendedor é capaz de reconhecer o potencial comercial da invenção e organizar o capital, o talento e outros recursos que transformam uma invenção em uma inovação comercialmente viável".

As atividades empreendedoras diferem substancialmente dependendo do tipo de organização e criatividade envolvidas. O empreendedorismo varia em escala, de projetos solo, em tempo parcial, à empreendimentos de larga escala que envolvem uma equipe e que podem criar muitos empregos (ALFREDO, 2011).

Por exemplo, existe o conceito de micro empreendedorismo, que é aquele que fornece alguma forma de subsistência para o proprietário, geralmente autônomo e sem funcionários (ACCENTURE, 2014). Esse tipo de empreendedorismo merece atenção, porque o micro-empreendedor pode estar empreendendo visando uma oportunidade ou então empreendendo por necessidade. O empreendedorismo por necessidade acontece por uma necessidade de sobrevivência e não apenas para aproveitar as 
oportunidades de mercado detectadas. Nesse caso, o negócio costuma ser aberto quando um indivíduo não possui alternativas para a geração de renda, algo que acontece bastante quando há crise na economia e altas taxas de desemprego ou por falta de capacitação específica para as demandas do mercado de trabalho, ocorrendo bastante em países pobres ou emergentes (NASSIF et al., 2009).

Nos últimos anos, a ampla adoção das tecnologias de informação e comunicação da internet móvel criaram uma noção de aumento das oportunidades empreendedora por mídias digitais, com o argumento de que os empreendimentos digitais demandam poucos recursos para sua criação e operação (MASON; CARTER; TAGG, 2011, KRAUS et al., 2018, STEININGER, 2018).

A popularização da internet, o avanço tecnológico bem como o desenvolvimento de um ecossistema digital vem proporcionando criação de novos negócios únicos que podem ser chamados de empreendedorismo digital (BANDERA; PASSERINI, 2020, NAMBISAN, 2017). Esse tema vem chamando a atenção dos pesquisadores e percebese um aumento dos estudos sobre empreendedorismo digital (KRAUS et al., 2018, ZAHEER; BREYER; DUMAY, 2019).

Nesse contexto torna-se fundamental não só entender o fenômeno do empreendedorismo digital em si, mas também compreender melhor as características dos indivíduos criativos que conseguem entender as mudanças de mercado e captam oportunidades geradas pelas tecnologias digitais (STEININGER, 2018, ZAHEER; BREYER; DUMAY, 2019).

\subsubsection{Empreendedorismo Digital}

As mudanças nos hábitos de consumo da mídia digital e na economia dos bens digitais favoreceram o desenvolvimento do empreendedorismo digital (GUTHRIE, 2014) e a tendencia de interesse crescente pelo tema se dá devido ao rápido desenvolvimento das tecnologias digitais e do surgimento da digital economy (ANIM-YEBOAH et al., 2020).

Contudo, ainda não há consenso entre os pesquisadores sobre a definição do termo "empreendedor digital" (KRAUS et al, 2018, NAMBISAN, 2017, ZAHEER; BREYER; DUMAY, 2019). Assim, "definir o empreendedorismo digital é uma árdua tarefa de inclusão e exclusão, pois nem todas as empresas que usam tecnologia digital devem ser consideradas digitais" (BANDERA; PASSERINI, 2020, p. 3).

A definição exata de empreendedorismo digital ainda está sendo debatida, em parte porque ainda é cedo e, em parte, porque é um alvo móvel. Conforme a tecnologia 
digital evolui, o que há de novo no empreendedorismo digital mudará com o tempo. Talvez, um dia, a maioria ou todos os empreendimentos empresariais vão nascer digitais, e o empreendedorismo digital como um tópico separado deixará de existir (ANDERSON, 2014). Hoje, no entanto, há uma necessidade real de preparar melhor os empreendedores para o mundo digital e de esclarecer melhor o empreendedorismo digital (ANDERSON, 2014).

Existem definições muito utilizadas na literatura, como por exemplo a de Davidson e Vaast (2010, p.2). Eles postulam que "o empreendedorismo digital é definido como a busca de oportunidades econômicas ou de negócios com base no uso de tecnologias digitais". Essa definição pode considerar um empreendedor digital aquele que utiliza tecnologia digital, mas possuí operações físicas de estoque, transporte e entrega. Porém, segundo Guthrie (2014), os negócios digitais ocorrem 100\% na internet e seus produtos e serviços são feitos de bytes, sem operações físicas.

Sendo assim, neste estudo, será utilizada a definição de Guthrie (2014, p. 115) que diz que "Empreendedorismo digital é a venda de produtos digitais ou serviços digitais por meio de redes eletrônicas".

Dheeryia (2009) é outro autor que concorda que o termo empreendedorismo digital deve ser usado para empreendimentos conduzidos exclusivamente na World Wide Web (WWW), rede mundial de internet.

A definição adotada por este estudo, apesar de simples e generalista, abrange os indivíduos que, por conta própria, buscam na internet uma forma de empreender. Algumas oportunidades requerem mais conhecimentos técnicos, mas outras estão ao alcance de qualquer pessoa que aprenda as habilidades básicas do empreendedorismo digital. Essas habilidades básicas incluem encontrar novos clientes online, criar protótipos de novas ideias de negócios e melhorar as ideias de negócios com base em dados (VON BRIEL et al., 2018).

Além de aprender novas habilidades práticas, o empreendedorismo digital também trata de novas maneiras de pensar sobre o empreendedorismo em si - o que é outra forma de dizer que oferece novas teorias de empreendedorismo. $O$ empreendedorismo digital abre novas questões sobre estratégia, oportunidade e risco (LYYTINEN et al., 2016).

Segundo Du et al. (2018), o empreendedorismo digital inclui tudo o que há de novo e diferente sobre o empreendedorismo em um mundo digital, incluindo: (a) novas formas de encontrar clientes para empreendimentos empresariais; (b) novas formas de projetar e oferecer produtos e serviços; (c) novas formas de gerar receita e reduzir custos; (d) novas oportunidades de colaboração com plataformas e parceiros e; (e) novas fontes de oportunidade, risco e vantagem competitiva. Em outras palavras, a 
digitalização da "tecnologia" não só muda suas propriedades, mas também impacta o processo global de empreendedorismo (NAMBISAN, 2017).

Nos últimos anos, o ambiente digital tem se apresentado como um espaço empreendedor único. As suposições de sua neutralidade e funcionalidade meritocrática sugerem que "qualquer um" pode criar um negócio na internet (KUESTER et al., 2018; GUTHRIE, 2014; ACCENTURE, 2014). Alguns autores discordam que o ambiente digital seja realmente meritocrático. Dy et al. (2017), por exemplo, ao pesquisarem sobre mulheres que empreendem digitalmente concluíram que o ambiente online reflete, reproduz e potencialmente exacerba as hierarquias sociais offline e diz que o preconceito que as mulheres enfrentam no setor de tecnologia tem a capacidade de restringir o potencial empreendedor delas no espaço online.

Ainda que a meritocracia do ambiente digital possa ser questionada, pode-se dizer que a economia dos bens de informação, a mudança dos hábitos de consumo digital (como por exemplo cada vez mais pessoas sentindo segurança em colocar os dados do cartão de crédito para compras online), a disponibilidade de ferramentas de produção de baixo custo (exemplo: softwares gratuitos para edição de vídeo, criação de design, etc.) e plataformas de distribuição de fácil acesso (Mercado Livre, Hotmart, Eduzz, Monetizze) favoreceram o surgimento da produção e distribuição digital em pequena escala (GUTHRIE, 2014). Além disso, empreendedorismo digital não requer instalações formais nem equipamentos caros e as operações podem ser flexíveis, embora algum conhecimento tecnológico seja requerido, ele é cada vez mais facilmente acessível.

Os empreendedores digitais muitas vezes não se preocupam diretamente com a tecnologia específica por trás de sua ideia de negócio, eles simplesmente se concentram no serviço que está baseado nela. Portanto, a tecnologia aqui é apenas um fator de entrada (GIONES \& BREM, 2017).

Em termos de aprendizagem, dada a facilidade em começar a empreender na internet, o empreendedorismo digital abre novas possibilidades para formar a próxima geração de empreendedores. A melhor forma de aprender empreendedorismo é 'fazer' e refletir sobre essa experiência (KUESTER et al., 2018). Standing e Mattson (2018) corroboram este ponto de vista ao apontar que empreendedores digitais tem uma perspectiva iterativa e aprendem dinamicamente durante o processo empreendedor em uma abordagem que pode ser melhor descrita como 'fingir até conseguir fazer'.

Vale ressaltar que o empreendedor digital é diferente da atividade do influenciador digital. No caso do influenciador digital, segundo Sibilia (2020, p.225), "a imagem de cada influenciador digital é a sua própria marca, um capital tão valioso que é necessário cuidá-lo e cultivá-lo a fim de encarar um personagem atraente no competitivo mercado dos olhares". No empreendedorismo digital a imagem pessoal não 
é tão relevante, ainda que possa ser usada. Tanto o influenciador digital quanto o empreendedor digital estão preocupados em gerar conteúdo nas redes, contudo, o primeiro busca conquistar seguidores e fama pessoal para usar como moeda de troca e permuta com empresas e parceiros e, o segundo, em geral, busca potenciais clientes (os quais são denominados de leads) para vender os seus infoprodutos ou o de terceiros (marketing de afiliados, o qual será explicado adiante). Assim sendo, o empreendedor digital tem um conjunto de habilidades especificas.

\subsubsection{Habilidades do empreendedor digital}

Bandera e Passerini (2020) pesquisaram os traços de personalidade do empreendedor digital, com o intuito de verificar se havia diferenças entre os empreendedores que lidam principalmente no domínio digital e os empreendedores que operam com produtos ou serviços mais tradicionais. Os autores concluíram que existem diferenças nos traços de personalidade de empreendedores tradicionais e digitais, principalmente em relação a visão de futuro.

Bandera e Passerini (2020) suspeitaram que, uma vez que os empreendimentos digitais dependem de infraestruturas relativamente novas (por exemplo, banda larga móvel), comportamentos de mercado (por exemplo, adoção de mídias sociais ou hábitos de compras online) e modelos de negócios (por exemplo, MercadoLivre ou Hotmart, que são plataformas que unem compradores e produtores), os empreendedores digitais precisariam estar constantemente focados na evolução de novas tecnologias e modelos de negócios e, portanto, estarem focados em eventos futuros. Contudo, esses autores encontraram resultados na direção contrária, isto é, empreendedores digitais estão menos focados no futuro do que empreendedores tradicionais. Enquanto empreendedores digitais veem as mudanças tecnológicas como oportunidades, os empreendedores tradicionais veem como ameaças e perigos ao seus modelos de negócios tradicionais.

Os empreendedores digitais aparecem como indivíduos confiantes no setor e capazes de converter a ansiedade que as mudanças tecnológicas podem proporcionar em oportunidades de negócios (BANDERA; PASSERINI, 2020).

O empreendedor digital tem a necessidade de buscar as oportunidades com base em mídia e tecnologias digitais por meio de uma estrutura de modelo de negócios fundamental que aproveita três componentes principais, sendo eles: back-office, 
marketing e transação (STANDING e MATTSSON, 2018). Já para Guthrie (2014), os empreendedores digitais possuem três habilidades básicas relacionadas a produção de conteúdo, distribuição (ou divulgação) e promoção (venda). Apesar de usarem nomenclaturas distintas, tanto Standing e Mattson (2018) como Guthrie (2014) concordam que o empreendedor digital precisa desenvolver ou aperfeiçoar um produto digital ou serviço (etapa de back office ou produção); fazer a distribuição desse produto ou serviço através das diferentes plataformas existentes e, por fim, usar todas as técnicas disponíveis para converter a venda desse produto ou serviço. A tabela 1 resume as habilidades básicas do empreendedor digital. 
Tabela 1 - Habilidades do empreendedor digital

Tabela 2

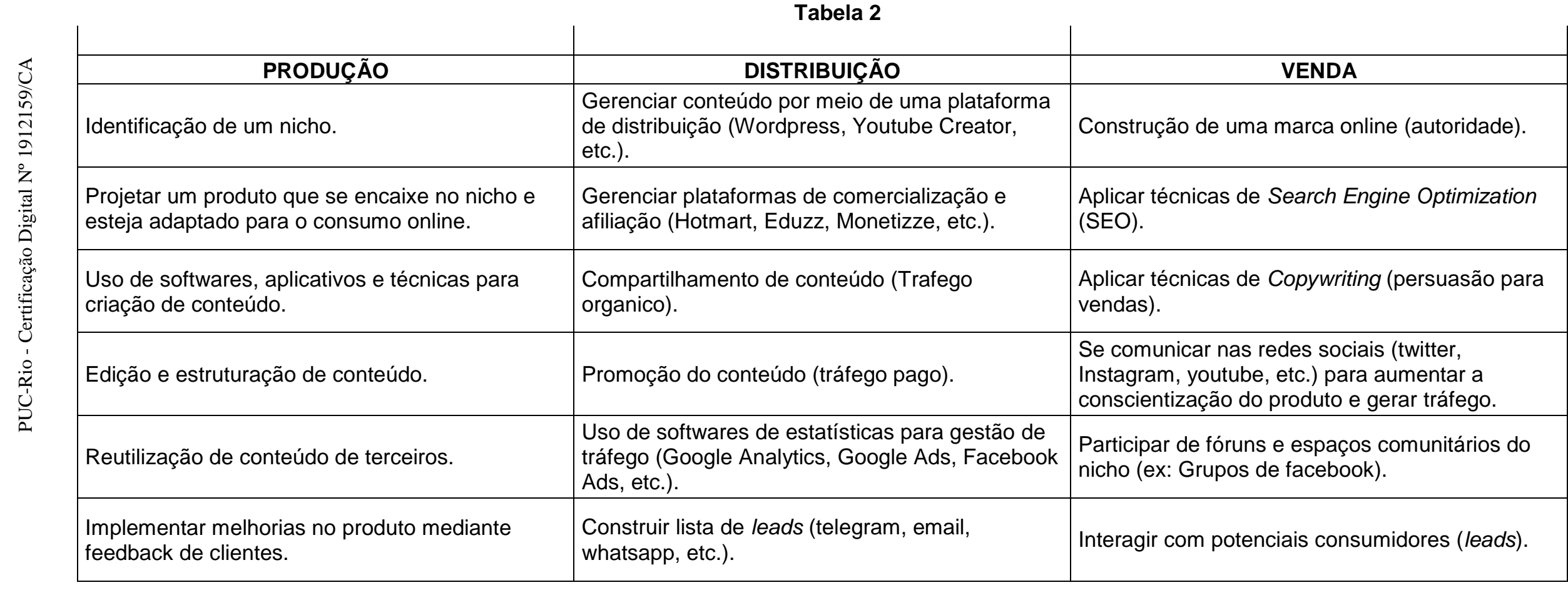

Fonte: Adaptado de Guthrie (2014) 
Em resumo, o empreendedor digital produz e vende bens digitais com base no conhecimento pessoal, experiência ou talento, usando ferramentas de multimídia onipresentes e os distribui em plataformas on-line acessíveis (GUTHRIE, 2014). No Brasil, alguns exemplos de plataformas de distribuição acessíveis que possibilitam a comercialização de produtos digitais (também chamados de infoprodutos) são o Hotmart, Eduzz, e Monetizze.

O potencial para que novos empreendimentos aprofundem sua especialização, ao mesmo tempo em que compensam suas capacidades de produção, marketing e distribuição explica a atratividade das plataformas digitais como um local para o empreendedorismo (NAMBISAN, 2017). Um exemplo de uma atividade empreendedora que se tornou possível após o surgimento dessas plataformas digitais foi o chamado marketing de afiliados, tema que será abordado na seção seguinte.

\subsubsection{Empreendedorismo Digital e Marketing de Afiliados}

Segundo Hoffman e Novak (2000), existem milhões de sites na internet competindo pela atenção de potenciais compradores. Por isso, os gastos em marketing digital para fazer com que o vendedor se destaque no meio da multidão são cada vez maiores. O custo para aquisição de um novo cliente é cada vez mais alto (HOFFMAN \& NOVAK, 2000). Uma alternativa ao marketing tradicional, onde se paga para anunciar, é o marketing de afiliados.

O marketing de afiliados é um tipo de marketing online cujo objetivo é o foco na obtenção de resultados (ZAPATA et al., 2021). Alguns sites e indivíduos que usam seus perfis na internet com fins de negócios podem ser chamados de afiliados quando realizam a divulgação e anúncios de infoprodutos de terceiros para obter uma comissão quando o usuário final realiza a ação previamente acordada (ZAPATA et al., 2021). Em resumo, o marketing de afiliados é um "vendedor virtual" que está promovendo produtos ou serviços digitais de terceiros em troca de uma comissão que, em geral, é paga quando a venda efetivamente acontece (ZAPATA et al., 2021; HOFFMAN; NOVAK, 2000). Ou seja, no marketing tradicional se paga para anunciar enquanto no marketing de afiliados se paga apenas quando a venda acontece (EDELMAN; BRANDI, 2015).

Segundo Edelman e Brandi (2015), os profissionais de marketing tradicional questionam a eficácia de suas campanhas publicitárias, pois pagam pela publicidade antecipadamente e recebem os benefícios posteriormente, ficando 
vulneráveis a veiculações de anúncios de baixo ou sem desempenho. Contra essa limitação do marketing tradicional, o marketing de afiliados oferece uma alternativa inovadora: uma abordagem baseada no desempenho no qual os anunciantes pagam apenas quando ocorre uma venda. Com um rastreamento online robusto (através de links e cookies) que atribui as vendas aos afiliados, os anunciantes percebem uma redução de risco sem precedentes (EDELMAN; BRANDI, 2015). Essa modalidade de monetização foi democratizada com o aparecimento de plataformas digitais voltadas exclusivamente para esse fim, como a Hotmart, Eduzz, Monetizze, Lomadee etc.

Conforme mencionado anteriormente, empreendedores digitais comercializam produtos ou serviços feito de bytes, isto é, $100 \%$ digitais (GUTHRIE, 2014). Em geral esses produtos são cursos online, e-books ou serviços de mentoria e consultoria. Os criadores destes produtos/serviços são chamados de infoprodutores. Contudo, como visto no tópico anterior, um empreendedor digital, além de habilidades de produção/criação, precisa dominar habilidades de marketing e habilidade de venda, do contrário não conseguirá se manter no mercado. Por isso o marketing de afiliados é uma modalidade de marketing fundamental para aqueles que seguem a carreira de empreendedor digital, porque um empreendedor que tenha grande habilidade para produzir e criar, mas não possui muitas habilidades de venda, pode disponibilizar seu produto para um empreendedor digital que possua a habilidade complementar de venda, mas não é tão hábil em criar/produzir um próprio produto ou serviço digital. Essa complementariedade ajuda na difusão e desenvolvimento desses empreendedores.

Em outras palavras, uma saída para os infoprodutores é disponibilizar seus produtos nas plataformas digitais disponíveis (ex: Hotmart, Eduzz, Monetizze, Lomadee, etc.) para que outros empreendedores digitais que dominam as habilidades de venda e marketing possam vender o produto ou serviço em troca de comissão. Vale ressaltar que uma atividade não impede a outra: um mesmo empreendedor digital pode tanto criar produtos como se afiliar a produtos de outros e ser comissionado pela venda. O surgimento desse ecossistema digital contribui para que mais indivíduos acreditem e apostem na carreira de empreendedor digital. Assim como o Youtube possibilitou a carreira de youtubere - Instagram possibilitou a carreira de Digital Influencer, as plataformas de marketing de afiliados (Eduzz, Hotmart, Monetizze, etc.) contribuíram para criar um ecossistema digital que possibilitou o surgimento da carreira de empreendedor digital, pois criar e comercializar produtos e serviços digitais se tornou mais fácil. 


\subsection{Desenvolvimento de Carreira}

Segundo Savickas (2012), os estudos sobre desenvolvimento de carreira podem ser divididos em três principais paradigmas. Os dois primeiros paradigmas possuem uma perspectiva modernista e o terceiro paradigma uma perspectiva pós modernista. A seguir serão explicados cada um desses paradigmas bem como a diferença entre a perspectiva modernista e a pós modernista.

\subsubsection{Perspectivas modernistas de carreira}

Donald Super (1957) talvez seja o autor mais citado quando o assunto é desenvolvimento de carreira. Seu livro intitulado "A psicologia das carreiras: uma introdução ao desenvolvimento vocacional" possuí mais de 7.600 citações acadêmicas, segundo o Google Scholar. Autor de um consagrado modelo de carreira, denominado modelo tradicional de Desenvolvimento de Carreira, Super (1957) afirma que as pessoas passam por cinco estágios de carreira.

O primeiro estágio é o de "crescimento", que acontece até os 14 anos de idade, onde o indivíduo aprende sobre o mundo do trabalho. O segundo estágio é o de "exploração", cuja principal preocupação do indivíduo é identificar seus interesses e capacidades e estabelecer-se em empregos que o interessem. Durante esta fase, que vai dos 15 aos 24 anos de idade, o indivíduo está familiarizando-se com o mundo do trabalho, desenvolvendo competências para funções organizacionais e profissionais e obtendo aceitação pelos pares. Posteriormente, no "estágio de estabelecimento", que vai dos 25 aos 44 anos de idade, o indivíduo se preocupa em dominar sua área de interesse identificada e em se tornar um especialista. Durante esse estágio, as pessoas desejam progredir na carreira, desenvolver uma vida profissional estável e alcançar a independência. Assim, os indivíduos nesse estágio focam na mobilidade ascendente, independência, realização e promoção. Depois, no quarto estágio, o "estágio de manutenção", que vai dos 45 aos 64 anos de idade, os indivíduos tentam manter seu autoconceito e se apegam às suas realizações anteriores para se firmarem em suas carreiras. Esta fase é caracterizada por uma ênfase reduzida na competição e mobilidade ascendente e maior preocupação com as relações profissionais e de pares (por exemplo, ajudar os outros e mentoria) e fortalecer a organização. Os indivíduos nesse estágio buscam maiores oportunidades de 
envolvimento e atribuições mais significativas. Finalmente, o quinto estágio é o "declínio", que acontece após os 65 anos de idade e o indivíduo prepara a sua aposentadoria (SUPER, 1957; KOOIJ e BOON, 2018).

Savickas (2012), outra referência importante e mais atual no debate sobre trajetória de carreira, pontua que a teoria de desenvolvimento de carreira de Super (1957) especifica tarefas previsíveis e comportamentos padronizados que os indivíduos adotam para desenvolverem suas carreiras. Ou seja, é uma teoria que visa padronizar a vida profissional das pessoas. Outro problema da teoria tradicional de desenvolvimento de carreira de Donald Super (1957) é que o termo carreira se limita apenas ao ambiente organizacional. Para Savickas (2015), essa padronização de trajetória de carreira, que cria roteiros rígidos a serem seguidos, não é mais adequada para descrever as carreiras nos dias de hoje, na medida em que a sociedade é marcada por incertezas e mudanças constantes.

Savickas (1997, p. 247) diz que Super "inicialmente confiou muito na teoria e nos métodos dos traços de personalidades" e esses métodos usados por psicólogos vocacionais "se baseiam no positivismo lógico" e o problema disso é posicionar os indivíduos como objetos (SAVICKAS, 2015). Em outras palavras, os psicólogos vocacionais e estudiosos de carreira tradicionais passaram muito tempo medindo a semelhança de pessoas com protótipos e grupos ocupacionais categorizados por traços de personalidade ou outras categorias essencialistas, como habilidades ou interesses (SAVICKAS, 2015). Todavia, com o surgimento constante de novas carreiras nos últimos anos, como a de empreendedor digital, youtuber e influenciador digital, os constructos de carreira que visam prescrever uma trajetória de carreira previsível para um indivíduo se tornam cada vez mais difíceis.

A virada do século $X X I$ apresentou vários desafios e questões no que diz respeito às carreiras e ao desenvolvimento de carreiras. Estudiosos passaram a entender que os desafios relacionados com a vida profissional provaram que as carreiras pertencem aos indivíduos e não às organizações como se pensava no século XX (SAVICKAS et al., 2009).

Vários conceitos de carreira emergiram para tentar explicar os diferentes tipos de carreira que estão sendo construídos no ambiente dinâmico de trabalho da atualidade (Sullivan e Baruch, 2009), tais como carreira sem fronteiras (ARTHUR, 1994) e carreira proteana (HALL, 1996). De forma resumida, o primeiro conceito tendia a focar nos movimentos geográficos e psicológicos que as pessoas faziam para desenvolver uma carreira, buscando cada vez menos vínculos com uma única organização (ARTHUR, 1994). No segundo, o foco 
estavam nas habilidades, conhecimentos e competências que um indivíduo utilizava para se adaptar a um ambiente em constante mudança de forma a manter a sua empregabilidade (HALL, 1996). Ambos os conceitos - carreira sem fronteiras e carreira proteana - foram muito estudados pela academia e trouxeram contribuições importantes para as pesquisas sobre carreira e desenvolvimento de carreira, contribuindo para revisão de alguns tópicos bem estabelecidos acerca deste tema como, por exemplo, a forma como os pesquisadores passaram a enxergar a aposentadoria, a forma de aprendizado e desenvolvimento individual, contribuições para as pesquisas sobre conflito trabalho-família, recompensas de carreira etc. (SULLIVAN E BARUCH, 2009).

No entanto, as teorias de desenvolvimento de carreira, incluindo as emergentes, são essencialmente objetivistas ou positivistas (BUJOLD, 2004). Exemplos de definições de carreiras objetivistas ou positivistas são as de Arnold (2011), que diz que carreira é a evolução sequencial das experiências de trabalho de um indivíduo ao longo do tempo, e a de Sullivan e Baruch (2009), que propõem que carreira pode ser definida como as experiências de um indivíduo relacionadas com o trabalho e outras experiências relevantes, tanto dentro quanto fora de uma organização, que forma um padrão único ao longo da vida deste indivíduo.

Tais definições focam nas posições ocupacionais e na trajetória de trabalho da pessoa. Porém, para Savickas (2010), essa forma de conceituar carreira como uma série de cargos que um indivíduo ocupa desde os anos escolares até a aposentadoria ou "carreira é uma sequência de cargos ocupados ao longo da vida" (SUPER, 1980, p.286) fazem com que o uso da palavra carreira se confunda com a burocracia e os valores da classe média. Além disso, essas definições focalizam no caminho que o indivíduo percorre, isto é, na trajetória dele.

Savickas (2010) lembra que a palavra carreira vem da palavra francesa carrière, que, em primeira instância, significa carruagem, transporte ou veículo e "as pessoas usam uma carreira ou veículo para percorrer o curso da vida" (SAVICKAS, 2010, p.43). Savickas (2010, p. 43) sugere que troquemos uma perspectiva positivista por uma perspectiva social construcionista, na qual a carreira "pode ser repensada como o veículo que detém e carrega significado". Isto é, ao invés de focar na trajetória/caminho, focar no veículo, que é a história que um indivíduo conta sobre sua vida profissional (SAVICKAS, 2010).

Assim sendo, antes de aprofundar nessa perspectiva social construcionista de carreira, a qual será a base deste estudo, vale destacar que ela representa o terceiro e mais atual paradigma no que tange aos estudos de carreira. Segundo 
Savickas (2012), os estudos sobre desenvolvimento de carreira podem ser divididos em três principais paradigmas.

O primeiro paradigma, também chamado de guia vocacional, consolidou tanto o trabalho de Super (1957), mencionado acima, como outros estudos que focaram nos traços de personalidade e nas semelhanças entre pessoas para desenvolver construtos a fim de guiar as carreiras das pessoas, tal como a teoria do hexágono de Holland (1997), que descreve seis principais traços de personalidade e indica quais perfis profissionais se encaixam melhor em determinados ambientes de trabalho. O paradigma "guia vocacional" tem como característica ser bastante objetivista e positivista e os estudos que o utilizam refletem as carreiras de antigamente, como a carreira organizacional, na qual as empresas eram responsáveis pelas carreiras de seus funcionários e suas trajetórias de carreiras previsíveis (SAVICKAS, 2012). Savickas (2012) usa a metáfora de atores sendo encaixados em papéis para explicar esse paradigma, pois os psicólogos vocacionais, consultores de carreira e estudiosos estavam interessados em estudar como se dava o encaixe de pessoas e cargos. Para Maree (2013), esse paradigma que buscava o ajuste ideal entre candidatos a emprego e possíveis empregos, serviram a um propósito útil para preparar pessoas nos previsíveis ambientes de trabalho do passado.

O segundo paradigma, chamado por Savickas (2012) de "career education", ou educação de carreira (em tradução livre), buscou aspectos mais subjetivos ao estudar o desenvolvimento de carreira dos indivíduos. Através de tarefas, os estudiosos e psicólogos vocacionais buscavam fazer com que seus clientes desenvolvessem organicamente uma ideia de carreira. Os estudos sobre carreira proteana (HALL, 1996) e carreira sem fronteiras (ARTHUR, 1994), citados anteriormente, bem como os estudos sobre carreira caleidoscópica (MAINIERO \& SULLIVAN, 2005), carreira portfolio, dentre outros, buscaram entender a trajetória do profissional responsável pela própria carreira, já que as organizações não mais cumpriam esse papel. Esses estudos, ainda que tenham considerado aspectos mais subjetivos de carreira, ainda focaram no caminho, na trajetória.

O terceiro paradigma, nomeado de "Life Design" por Savickas et al. (2009), ou "Construção da Vida", em tradução oficial, tem por base uma perspectiva social construcionista e acredita que o foco deve ser o veículo e não o caminho. veículo que leva uma pessoa de uma carreira a outra são as histórias que ela conta. Uma pessoa é autora de sua própria carreira ao projetar sua história e desenvolver sua própria narrativa de vida. Esse paradigma, segundo Maree (2013), pode ser considerado pós-modernista, termo guarda-chuva que abriga as 
teorias de carreira que abordam o tema fazendo uso de narrativas e histórias para interpretar subjetivamente e objetivamente a carreira das pessoas.

O tópico a seguir será dedicado a aprofundar o entendimento das teorias pós-modernistas de carreiras a fim de explicar os motivos pelos quais a visão social construcionista de Savickas foi usada neste estudo para analisar a carreira dos empreendedores digitais. A tabela 2 resume a retórica e o repertório usado por cada um dos 3 paradigmas de desenvolvimento de carreira.

3

Tabela 4 - Desenvolvimento de carreira: retórica e repertórios

\begin{tabular}{|c|c|c|c|}
\hline 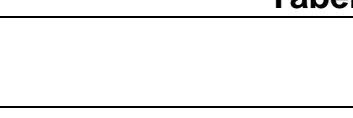 & $\begin{array}{l}\text { 1) Orientação } \\
\text { Vocacional }\end{array}$ & $\begin{array}{l}\text { 2) Educação em } \\
\text { Carreira }\end{array}$ & 3) Life Design \\
\hline $\begin{array}{l}\text { Considera } \\
\text { aspectos }\end{array}$ & Objetivos & Subjetivos & Projetivos \\
\hline $\begin{array}{l}\text { Metáfora usada } \\
\text { para explicar }\end{array}$ & $\begin{array}{l}\text { Atores sendo } \\
\text { encaixados em } \\
\text { papeis }\end{array}$ & $\begin{array}{c}\text { Agentes } \\
\text { responsáveis pelo } \\
\text { próprio } \\
\text { desenvolvimento } \\
\end{array}$ & $\begin{array}{c}\text { Autores de histórias } \\
\text { autobiográficas }\end{array}$ \\
\hline $\begin{array}{c}\text { Método } \\
\text { comumente usado }\end{array}$ & $\begin{array}{l}\text { Testes e traços de } \\
\text { personalidade }\end{array}$ & Tarefas e exercícios & Temas \\
\hline Objetivo & $\begin{array}{l}\text { Encaixe de } \\
\text { profissões }\end{array}$ & $\begin{array}{l}\text { Desenvolvimento } \\
\text { individual }\end{array}$ & $\begin{array}{c}\text { Autocriação/ } \\
\text { desenvolvimento do } \\
\text { autoconceito }\end{array}$ \\
\hline $\begin{array}{l}\text { Resultados } \\
\text { esperados }\end{array}$ & $\begin{array}{c}\text { Identificar } \\
\text { semelhanças de } \\
\text { perfis }\end{array}$ & $\begin{array}{l}\text { Prontidão individual } \\
\text { e manutenção da } \\
\text { empregabilidade }\end{array}$ & $\begin{array}{c}\text { Reflexão individual e } \\
\text { construção } \\
\text { identitária }\end{array}$ \\
\hline
\end{tabular}

Fonte: Adaptado de SAVICKAS (2012).

\subsubsection{Perspectivas pós-modernistas de carreira}

Blustein et al. (2004) afirmam que as narrativas apresentam uma perspectiva inovadora que possibilita uma melhor compreensão das carreiras.

O recente aumento do uso de histórias, narrativas e conversações como representações do significado de carreira ajudam a constituir uma estrutura mais contextual nas teorias sobre desenvolvimento de carreira. Uma implicação importante desse foco no contexto das teorias atuais é a consciência de que múltiplas verdades existem na maneira como cada pessoa constrói suas 
percepções e narrativas sobre suas experiencias profissionais (BLUSTEIN et al., 2004). As perspectivas pós-modernistas de carreira, contudo, podem ser divididas entre o construtivismo e o social construcionismo.

O construtivismo tem sido definido como algo relacionado ao processo cognitivo envolvido na construção do conhecimento e experiencias de mundo (BUJOLD, 2004). Desenvolvimento de carreira, no nível individual, pode ser considerado um processo criativo, já que requer múltiplas decisões, envolve riscos e pessoas necessitam desenvolver maneiras únicas para lidar com obstáculos, eventos incertos, circunstâncias nem sempre favoráveis e conflitos inerentes (BUJOLD, 2004). Olhando por este ângulo, a aplicação de narrativas para entender o fenômeno se mostra ainda mais adequada, já que o conhecimento gerado pelas narrativas leva em consideração a criatividade e imprevisibilidade das pessoas (BUJOLD, 2004).

Contudo, essa abordagem põe demasiada ênfase no indivíduo e limita o contexto relacional. Alguns autores construtivistas ainda tentam incluir o contexto social em suas definições, como é o caso de Young \& Collin (2004), que afirmam que o construtivismo se concentra em como os indivíduos se envolvem cognitivamente na construção do conhecimento dentro de um mundo social que afirma que o conhecimento, bem como os significados de certos termos foram histórica e culturalmente construídos em relação às ações e processos sociais. Esta perspectiva epistemológica aplicada ao tema de carreira põe ênfase no indivíduo e na maneira como ele adquire o conhecimento, suas implicações, como eles atribuem significados ao que eles experienciam ao longo da vida.

No entanto, as teorias de carreira, em geral, têm sido criticadas por enfatizar demais a agência individual, enquanto negligenciam as questões contextuais (BROWN, 2002). Logo, é preciso considerar que as diferentes forças contextuais (história, cultura e ideologia) contribuem para a objetificação da realidade social da carreira e impactam diretamente as definições de carreira (DRIES, 2011).

Por outro lado, à luz da visão construcionista social, as carreiras são inerentemente inseridas em contextos sociais, pois é quase impossível considerar o trabalho sem considerar o contexto relacional em que o trabalho ocorre, bem como os papéis da vida que se mesclam com o tipo de trabalho que se faz (BLUSTEIN et al., 2004). Carreira abrange toda vivência laboral de um indivíduo ao longo da vida que reflete vontade intencional para com suas próprias tarefas e trabalhos, sempre motivado pela necessidade de sobrevivência (BLUSTEIN et al., 2004). 
A fim de compreender a própria carreira, o indivíduo deve passar primeiro pelos processos cognitivos individuais, que incluem a auto-organização e a auto concepção, que são componentes-chave na compreensão do comportamento humano, uma vez que os locais de trabalho contam com uma rede de pessoas conectadas. A partir daí, compreender novas carreiras requer o conhecimento construído a partir de relações que possuem contextos socioeconômicos, culturais e sociopolíticos, ao invés do conhecimento possuído por um único indivíduo. $\mathrm{Na}$ verdade, os construcionistas sociais acreditam que quando um indivíduo muda de uma perspectiva individual para uma perspectiva de relacionamento, ele entra em um espaço compartilhado onde a compreensão, o conhecimento, bem como várias perspectivas são criados e recriados (BLUSTEIN et al., 2004).

Neste sentido, a teoria de Savickas et al. (2009), conhecida por "Life Design", se mostra adequada não só para os profissionais de psicologia vocacional e conselheiros de carreira que visam ajudar as pessoas a se entenderem melhor neste mundo moderno e tecnológico, mas também pode ajudar pesquisadores que buscam entender o fenômeno do surgimento de novas carreiras, como a do empreendedor digital. Isso porque, através da reflexão sobre os temas de sua vida, um indivíduo é capaz de traçar uma narrativa na qual ele pode chamar de carreira. Esse entendimento envolve aspectos objetivos e subjetivos e envolve mais do que o ambiente profissional (SAVICKAS, 2012). Ao analisar a história que os empreendedores digitais contam sobre suas carreiras, considerando que eles estão inseridos num contexto social extremamente dinâmico e que eles possuem diversas atividades profissionais, várias aspirações, desenvolvem diferentes habilidades e convivem num mundo de muitas transformações, falar somente de carreira (no sentido modernista do termo) não traduz a essência desses profissionais.

Uma vez que a vida profissional é uma série de projetos sucessivos que vão sendo construídos socialmente (SAVICKAS, 2002), a autobiografia que um indivíduo constrói sobre o trabalho compõe uma carreira subjetiva que impõe coerência e continuidade na explicação do comportamento vocacional ao longo do tempo (SAVICKAS, 2010). Uma crônica pessoal carece de um enredo ocupacional. Portanto, o currículo de uma pessoa é um relatório factual e cronológico de uma carreira objetiva, enquanto a carreira subjetiva é construída pelo indivíduo através da história que ele conta da sua própria vida (SAVICKAS, 2010).

A incorporação não só dos significados objetivos, mas também dos significados subjetivos que as pessoas atribuem às suas carreiras e histórias de 
vida é fundamental para que elas façam boas escolhas de carreira e construam projetos de vida bem-sucedidos (MAREE, 2013). Por isso é importante estudar os significados objetivos e subjetivos que os empreendedores digitais atribuem às suas carreiras, pois sendo uma carreira "nova", este entendimento pode contribuir para os estudos sobre novas carreiras digitais.

As pessoas usam histórias para organizar suas vidas, construir suas identidades e dar sentido a seus problemas. As histórias que as pessoas contam têm um jeito de cuidar delas. Permanecer em suas próprias histórias muitas vezes desestabiliza velhas ideias que bloqueiam a tomada de decisão e geralmente permite uma consciência que leva a uma escolha. À medida que os indivíduos dão voz às suas histórias, eles ouvem o que já sabem e encontram as respostas que procuram. De seu próprio conhecimento emerge uma nova perspectiva que permite aos indivíduos imaginar uma história de identidade revisada. Do ponto de vista da nova perspectiva, os indivíduos elaboram ou mudam suas histórias de maneiras que clarificam as escolhas e estimulam ações transformadoras para fazer a transição de carreira (SAVICKAS, 2015).

Segundo Dix (2020), a construção da carreira através de narrativas pode preparar as pessoas para desenvolverem resiliência em face de um cenário profissional em mudança; pode ajudar os indivíduos a se relacionarem melhor com o outro e com as diversas comunidades das quais fazem parte; e ajudar o indivíduo a se relacionar com questões abstratas mais amplas, tais como verdade, justiça e igualdade. Talvez seja por isso que a teoria do Life Design mereça ser vista como uma forma valiosa de escrita de vida, porque, no mundo em mudança do século $\mathrm{XXI}$, essas próprias mudanças precisam cada vez mais ser interrogadas e abordadas de novas maneiras (DIX, 2020).

Assim, ainda que o Life Design ou Construção da Vida (SAVICKAS et al., 2009) seja uma teoria que visa orientar conselheiros de carreira e psicólogos vocacionais a ajudarem seus clientes por meio de coautoria em histórias autobiográficas, isso não significa que o Life Design ou Construção da Vida não possa ser usado para fornecer uma lente através do qual a análise textual possa ser realizada (DIX, 2020). Pelo contrário, um dos benefícios potenciais derivados de trazer o Life Design para o domínio das pesquisas qualitativas que visam entender as "novas carreiras" é fornecer um novo meio de explorar como trabalho, vida profissional, vocações e carreiras foram representadas em formas de histórias, ficcionais e não ficcionais. Ao transcrever as narrativas de carreira de uma pessoa que está atuando em um novo campo, o que surge é um relato dinâmico da inter-relação entre os componentes materiais do autor da carreira e 
um texto que reflete os diversos estágios dessa carreira bem como tem um impacto na construção dela de forma material.

Em outras palavras, inicialmente o Life Design foi concebido para ser uma forma de aconselhamento baseada numa interação interpretativa mútua, posicionando o cliente e o conselheiro como sujeitos. Em vez de pontuações de testes que indiquem com quem os clientes se parecem, o Life Design usa histórias que mostram a singularidade de cada cliente. Resumidamente, a orientação vocacional se concentra nas pontuações, nos testes e nos traços de personalidade, enquanto o Life Design se concentra nas histórias (SAVICKAS, 2015).

Contudo, uma narrativa, para a pessoa que está contando a história, se torna um processo dado que, ao atribuir significados a uma experiencia, essa pessoa forma a construção do eu e a autoconsciência. Mas a narrativa não é só um processo, é também um produto, já que o resultado é uma história autobiográfica. Além disso, a pessoa que elabora a narrativa, além de ser autora, também é a protagonista da história e, na maioria das vezes, ela é a principal ouvinte/leitora, já que elabora a narrativa para uso próprio, seja para organizar fatos e acontecimentos do passado de forma coerente seja para buscar respostas para o que ela procura para seu futuro. Assim sendo, quem faz o uso de narrativas para dar sentido à própria carreira tem tripla função: autor, protagonista e ouvinte/leitor (DIX, 2020), o que "permite que o indivíduo em questão veja sua vida de um ponto de vista imaginário fora dela, alcançando assim um grau de distância crítica e novas formas de autoconhecimento e compreensão" (DIX, 2020, p.2).

Um exemplo do Life Design aplicado na prática pode ser encontrado no artigo de Huang (2020) que analisou como os escritos autorreflexivos de médicos chineses remodelaram suas visões sobre as ideias de doença, seus relacionamentos com outras pessoas nos hospitais e suas identidades como médicos. Huang (2020) descobriu que o ato de escrever sobre si mesmos ajudou os médicos a criarem um contexto no qual ciência e humanidade, passado e presente, e o indivíduo e sua comunidade estão todos inter-relacionados.

Considerando que apenas quando as transições de vida são contadas retrospectivamente em histórias e são atribuídos significados é que as transformações do eu acontecem (BUJOLD, 2004), é de se esperar que os empreendedores digitais, por exemplo, para autodenominarem-se dessa maneira, já possuam, ao menos, micronarrativas construídas e legitimadas nas relações psicossociais e baseadas nos discursos sociais disponíveis que os posicionem de forma individualizada como tal. 
Logo, as narrativas de carreira que as pessoas contam tanto para conselheiros de carreira como para professores, pesquisadores, amigos ou familiares são a forma de desenvolverem suas carreiras. Savickas (2012) relata que ele próprio passou para o terceiro paradigma do aconselhamento de carreira (Life Design) ao focar suas entrevistas em fazer perguntas aos indivíduos que os levassem a narrar suas experiências de vida pessoal e profissional, ajudando-os a ganhar consciência de suas carreiras.

As narrativas dão compreensão aos propósitos da vida à medida que se juntam aos eventos e ações diárias da vida de uma pessoa, proporcionando assim uma estrutura para a compreensão dos eventos do passado e permitindo que se planeje o futuro (SAVICKAS et al., 2009).

Ao tentar compreender o processo que leva o empreendedor digital a forjar sua identidade psicossocial, este trabalho recorreu à teoria de Savickas para compreender o fenômeno.

\subsubsection{Sucesso na carreira}

Gunz e Peter (2005) dizem que uma pessoa mede seu sucesso olhando para trás em sua trajetória de vida e avaliando quais mudanças ocorreram, sejam positivas ou negativas, depois disso, se o positivo supera o negativo, ou se o indivíduo alcançou alguns dos objetivos originais, então ele se considerará bemsucedido.

Segundo Dries (2011), a construção do sucesso na carreira evoca nas pessoas uma imagem objetificada da carreira - imagem com a qual elas podem ou não se identificar. Isto é, existe uma tendência de as pessoas enxergarem as carreiras como construtos sociais reais e fixos, ao invés de realidades sociais complexas e dinâmicas que podem ser (re)interpretadas e (re)moldadas de diferentes maneiras (DRIES, 2011). Essa (re)interpretação e (re)molde dos conceitos de carreira, num nível individual, ajuda os profissionais a se adequarem mais rapidamente às "novas" carreiras, como a do empreendedor digital. Em outras palavras, enquanto algumas pessoas enxergam a atividade apenas como um hobby, por que possuem uma visão de carreira muito objetificada, outras pessoas enxergam essa atividade como promissora e cheia de sentidos porque entendem a dinamicidade de nossos contextos sociais. 
Contudo, dizer que sucesso é definido por cada indivíduo e que cada pessoa é a única responsável por dizer o que é o sucesso, além de mais uma vez enfatizar demais a agência individual, também ignora o fato de que, sendo o sucesso na carreira um conceito socialmente constituído, as interpretações subjetivas das pessoas (seja o sucesso como um resultado positivo ou apenas uma sequência de eventos) pode desencadear padrões de entendimentos compartilhados entre pessoas que compartilham um mesmo contexto social (GUNZ E HESLIN, 2005). Assim sendo, entender quais os entendimentos sobre sucesso que os empreendedores digitais compartilham também pode ajudar a entender melhor sobre esta carreira. 


\section{3 \\ Metodologia}

Este capítulo apresenta as diversas decisões acerca da forma como este estudo foi realizado. Está dividido em cinco seções que informam, respectivamente, sobre o tipo método de pesquisa utilizado, sobre os critérios de seleção de sujeitos que compõem a amostra, sobre os processos de coleta de dados realizados e sua justificativa, sobre os procedimentos de tratamento dos dados coletado e, por fim, sobre as possíveis repercussões que as decisões sobre como realizar o estudo impuseram aos resultados assim obtidos.

\section{1. Método de pesquisa}

O presente estudo buscou entender como a carreira de empreendedor digital é construída objetiva e subjetivamente por aqueles que se dedicam a tal atividade. A partir deste objetivo, a estratégia de pesquisa qualitativa se mostrou adequada, dado que, de acordo com Creswell (2003), os métodos qualitativos são comumente usados em campos que são novos e requerem projetos de pesquisa mais exploratórios e, segundo Anim-Yeboah et al. (2020) empreendedorismo digital pode ser considerado uma área de pesquisa nova.

Dessa forma, foram entrevistados indivíduos que se autodefiniam como empreendedores digitais. Além disso, considerando que narrativas são esquemas que os seres humanos usam para dar sentido às suas experiências e ações pessoais e que as histórias contadas pelas pessoas não deveriam ser consideradas como uma verdade objetiva, mas como uma interpretação do indivíduo sobre o significado e o sentido de sua vida (BUJOLD, 2004), optou-se, na presente dissertação, por uma pesquisa baseada em entrevistas em profundidade e análise temática das narrativas obtidas. Neste paradigma, os achados da pesquisa não são considerados fatos objetivos, ao contrário, admitese que os resultados são interpretações feitas pelo pesquisador sobre as interpretações dos sujeitos. As narrativas são particularmente úteis no caso de projetos que investigam acontecimentos específicos, especialmente assuntos "quentes" (BAUER E GASKELL, 2003). 
As entrevistas foram feitas com base em um roteiro semi-estruturado contendo cinco perguntas abertas principais, sendo elas: (a) "Como sua carreira como empreendedor digital começou?"; (b) "Você teve ajuda de alguém nessa jornada de carreira?"; (c) "Qual o papel do networking para sua carreira de empreendedor digital?"; (d) "Quais são os seus planos para o futuro?”; (e) "Você considera sua trajetória bem sucedida? Por que?".

Essas perguntas serviram de guia para os sujeitos de pesquisa contarem as suas histórias de carreira. A ideia era fazê-los relatar a própria história, de modo que fosse possível identificar, em suas falas, os principais marcos objetivos de suas trajetórias bem como os pontos de construção identitária de suas carreiras, isto é, os grandes temas que os fizeram autodenominarem-se empreendedores digitais.

\section{2. \\ Seleção dos sujeitos}

Através das redes sociais Linkedln e Instagram buscou-se pessoas que se denominavam "empreendedores digitais" em seus perfis. Dentre aqueles que retornaram aos convites para a entrevista, checou-se aqueles que efetivamente ganhavam a vida, isto é, obtinham a totalidade de sua renda advindas de negócios online. A partir das entrevistadas iniciais, foram solicitadas indicações de amigos e conhecidos que atuavam no mesmo ramo, utilizando-se a técnica conhecida como "bola de neve" para chegar ao conjunto final de entrevistados.

Além de se autodeclarar empreendedor digital e de ter a totalidade da renda advinda de negócios online, outro critério utilizado foi que o sujeito de pesquisa deveria ofertar, necessariamente um produto ou serviço $100 \%$ digitais, feitos de bytes, sem estoque ou entrega de produtos físicos. Esses critérios acabam por excluir freelancers ou autônomos que ofertam serviços, por exemplo, de criação de websites ou serviços de design gráfico em plataformas especializadas onde os profissionais podem deixar seus portfólios à mostra e serem contratados por clientes interessados, como é o caso da plataforma "Workana" ou "Fiverr", pois, apesar de serem prestadores de serviços digitais, eles ou não se autodenominam empreendedores digitais ou usam esses serviços como complemento de renda.

Além disso, o critério de ter que comercializar algum tipo de produto ou serviço digital acabou por excluir do conjunto de entrevistados os youtubers, 
influenciadores digitais, blogueiros e outros tipos de atividades online que são remuneradas por visitação em suas páginas, sem a necessidade de comercializar um produto ou serviço. Em outras palavras, ser apenas um criador de conteúdo buscando remuneração por número de visualizações não se encaixa na definição de empreendedor digital considerada neste estudo (definição de GUTHRIE, 2014 apresentada no tópico 2.1.2) e, portanto, não se encaixa nos critérios para ser sujeito de pesquisa. Pela mesma razão, aqueles que usam o ambiente digital para vender produtos como canecas, camisetas, bolos e serviços físicos, como dentistas, também não entraram neste estudo.

Partindo-se desses critérios foram entrevistados 13 indivíduos, corpus considerado adequado para uma pesquisa qualitativa, segundo Gaskell (2008). Os respondentes representaram diferentes faixas etárias (de 26 até 47 anos), escolaridade (de fundamental incompleto até pós-graduado), regiões onde residem ( 7 diferentes estados brasileiros), sendo 9 homens e 4 mulheres.

A tabela 3 resume o perfil dos entrevistados. 
Tabela 5 -Perfil dos entrevistados

\begin{tabular}{|c|c|c|c|c|c|c|c|c|c|c|}
\hline $\begin{array}{l}\text { Nome } \\
\text { Fictício }\end{array}$ & Participante & Idade & Sexo & Localidade & Casado? & Filhos & Formação & $\begin{array}{l}\text { Área de } \\
\text { Formação }\end{array}$ & $\begin{array}{c}\text { Última ocupação antes de } \\
\text { viver do } \\
\text { empreendedorismo digital }\end{array}$ & $\begin{array}{c}\text { Tempo de } \\
\text { atividade como } \\
\text { Empreendedor } \\
\text { digital }\end{array}$ \\
\hline Anderson & E1 & 37 & Homem & Barueri, SP & $\operatorname{sim}$ & 2 & Fundamental & & Açougueiro & 12 anos \\
\hline Bráulio & E2 & 46 & Homem & Bagé, RS & $\operatorname{sim}$ & 2 & Fundamental & & Vendedor Externo & 11 anos \\
\hline Carlos & E3 & 37 & Homem & Pelotas, RS & $\operatorname{sim}$ & 1 & Fundamental & & Músico & 10 anos \\
\hline Daniel & E4 & 45 & Homem & Mauá, SP & $\operatorname{sim}$ & 2 & Superior & $\begin{array}{l}\text { Gestão da } \\
\text { Qualidade }\end{array}$ & Metalúrgico & 7 anos \\
\hline Enzo & E5 & 40 & Homem & Alvorada, RS & $\operatorname{sim}$ & 2 & $\begin{array}{l}\text { Fundamental } \\
\text { Incompleto }\end{array}$ & & Frentista & 7 anos \\
\hline Flávio & E6 & 38 & Homem & Vitória, ES & $\operatorname{sim}$ & 0 & Superior & Marketing & Técnico de Informática & 11 anos \\
\hline Gabriel & E7 & 47 & Homem & Linhares, ES & $\operatorname{sim}$ & 2 & Pós-graduação & $\begin{array}{l}\text { Sistemas de } \\
\text { Informação }\end{array}$ & Professor Universitário & 10 anos \\
\hline Hugo & E8 & 31 & Homem & Itatiaia, RJ & $\operatorname{sim}$ & 2 & Superior & Marketing & Vendedor Externo & 7 anos \\
\hline lago & E9 & 35 & Homem & Três Pontas, MG & $\operatorname{sim}$ & 0 & Superior incompleto & & Dono de Lan House & 11 anos \\
\hline Jaqueline & E10 & 39 & Mulher & Florianópolis, SC & $\operatorname{sim}$ & 1 & Médio & & Gerente de Call Center & 7 anos \\
\hline Karine & E11 & 26 & Mulher & Indaiatuba, SP & não & 0 & Superior & $\begin{array}{l}\text { Recursos } \\
\text { Humanos }\end{array}$ & Analista de RH & 2 anos \\
\hline Laura & $\mathrm{E} 12$ & 27 & Mulher & São Gonçalo, RJ & $\operatorname{sim}$ & 0 & Superior incompleto & & $\begin{array}{c}\text { Estagiária em grande } \\
\text { empresa }\end{array}$ & 2,5 anos \\
\hline Maysa & E13 & 41 & Mulher & Brasília, DF & $\operatorname{sim}$ & 3 & Superior & Nutrição & Nutricionista & 2,5 anos \\
\hline
\end{tabular}




\subsection{Coleta de Dados}

As entrevistas duraram entre $29 \mathrm{~min}$ a $69 \mathrm{~min}$ e foram realizadas através do software de videoconferência chamado Zoom. As entrevistas foram gravadas com a autorização dos entrevistados e posteriormente transcritas. Seguindo os apontamentos de Gaskell (2008, p.82), "a entrevista começa com alguns comentários introdutórios sobre a pesquisa, uma palavra de agradecimento ao entrevistado por ter concordado em falar, e um pedido para gravar a sessão." A partir deste momento, foi assegurada a confidencialidade do material gravado coletado, para que o sujeito ficasse à vontade para dar seu depoimento de maneira espontânea.

\subsection{Tratamento dos dados}

Para interpretar os dados obtidos optou-se pela análise temática das entrevistas buscando compreender, nas narrativas, quais os grandes temas que marcam objetiva e subjetivamente a carreira como empreendedor digital individual.

Segundo Souza (2019, p.52), a "análise temática é um método de análise qualitativa de dados para identificar, analisar, interpretar e relatar padrões (temas) a partir de dados qualitativos". Uma análise temática tanto pode proporcionar uma organização e descrição dos dados em ricos detalhes como pode resultar em uma ampla e complexa análise interpretativa sobre os dados (SOUZA, 2019).

Uma análise temática busca identificar os temas durante as entrevistas e 0 processo de identificação dos grandes temas é chamado de codificação (EZZY, 2002). Portanto, os temas encontrados neste estudo foram obtidos a partir da codificação dos dados obtidos nas 13 entrevistas.

Uma especificidade da análise temática é que, diferentemente do método de análise de conteúdo, as categorias não precisam ser estabelecidas antes da coleta dos dados, isto é, na análise temática as categorias podem emergir das entrevistas (EZZY, 2002). Uma vez que as categorias de análise não são predeterminadas, o pesquisador pode encontrar questões e problemas de pesquisa que não foram antecipados (EZZY, 2002), o que se mostra apropriado para este estudo uma vez que existem poucos estudos sobre a figura do empreendedor digital (ANIM-YEBOAH et al., 2020).

A opção pela análise temática neste estudo se deve ao fato dela ser útil em áreas de pesquisas novas (SOUZA, 2019) e, como vimos, o empreendedorismo digital é um 
campo novo (ANIM-YEBOAH et al., 2020). Além disso, a análise temática é compatível com o paradigma construcionista dentro da psicologia (BRAUN; CLARKE, 2006) e a teoria do Life Design (SAVICKAS et al., 2009) parte de uma perspectiva social construcionista que acredita que as carreiras são reconstruídas na medida que os indivíduos refletem sobre os temas de suas vidas (SAVICKAS, 2012). Por conseguinte, a análise temática pode ajudar a identificar e analisar os temas evidenciados pelos profissionais entrevistados que reconstruíram suas carreiras no empreendedorismo digital.

\subsection{Limitações do estudo}

Segundo Maree (2013) alguns estudiosos questionam as abordagens pósmodernas qualitativas sobre carreiras. Tais estudiosos acreditam que não foi "provado" que uma abordagem diferente para a carreira seja necessária, isto é, para eles não há justificativa empírica suficiente para o uso de uma abordagem qualitativa e que também existem dados insuficientes para sugerir que as abordagens baseadas nas narrativas tragam resultados melhores do que abordagens positivistas (MAREE, 2013). Em outras palavras, outros estudos podem fazer uso da teoria de estágios de carreira de Donald Super (1957) para analisar os empreendedores digitais, já que esta teoria tem servido tão bem aos praticantes e teóricos de carreiras. Contudo, neste estudo optou-se pela abordagem de narrativas e uma ênfase na teoria do Life Design (SAVICKAS et al., 2009) haja vista a dinamicidade e fluidez com que os empreendedores digitais vêm gerenciando suas carreiras. Tal abordagem qualitativa pode elucidar questões subjetivas atreladas não só a carreira de empreendedores digitais, mas também às novas carreiras que vem surgindo na internet. 


\section{Análise e Discussão dos Resultados}

Este capítulo traz os resultados obtidos após a realização das entrevistas em profundidade com os sujeitos selecionados e as análises pertinentes aos temas abordados. Está dividido em quatro partes principais. A primeira parte apresenta e discute os perfis e nichos de atuação dos empreendedores digitais. Em seguida é feita uma análise dos aspectos objetivos da carreira do empreendedor digital. Posteriormente, são discutidos os aspectos subjetivos dessa carreira e, por fim, é apresentada uma análise sobre a construção identitária do empreendedor digital.

\subsection{Análise do perfil e nichos de atuação dos entrevistados}

O presente item buscou abordar aspectos relativos ao contexto de modo a entender as possibilidades associadas, os interesses individuais envolvidos e entender a forma e as áreas de atuação desses empreendedores digitais.

Ao conduzir as entrevistas foi possível perceber que a maioria daqueles que se autodenominam empreendedores digitais nas redes sociais o fazem como sinônimo do trabalho com marketing digital. Nas falas abaixo, por exemplo, o termo "marketing digital" foi usado como sinônimo de "empreendedorismo digital".

"Mas eu comecei no marketing digital aí mesmo, por volta de 2010, cara." (Anderson).

"Foi só com a experiência dentro do marketing digital que eu aprendi mesmo." (lago).

Uma possível explicação para isso pode estar no critério e na técnica utilizadas para escolher os sujeitos dessa pesquisa, já mencionados. Ao procurar pessoas que se autodenominam empreendedores digitais nas redes sociais e pedir a essas pessoas que indicassem amigos que atuassem na mesma área, fui levado à entrevistados que atuam dentro do nicho marketing digital, mais especificamente indivíduos que almejam por explorar as oportunidades fornecidas pelas plataformas de marketing de afiliados, isto é, pessoas que vendem produtos ou serviços digitais ligados à alguma expertise dentro do marketing digital. Em outras palavras, aqueles que se dedicam a ser infoprodutores e/ou afiliados devem dominar a produção, o marketing e a venda para serem bem-sucedidos na área (GUTHRIE, 2014; STANDING E MATTSON, 2018) e o 
primeiro passo na hora de empreender online é a escolha do nicho em que se vai atuar (GUTHRIE, 2014). Ao que parece, quem atua num nicho muito específico (como ensinar a fazer bolos e confeitaria, por exemplo) ou não se autodenomina empreendedor digital ou não coloca essa denominação em suas redes sociais, mesmo que seu produto seja a venda de cursos online, somente. Em outros termos, o indivíduo que se dedica a vender cursos online que ensinem a fazer bolos, provavelmente se autodenomina "confeiteiro" ou outro termo que remeta ao conteúdo do curso que está vendendo, ao invés de se autodenominar "empreendedor digital", não só porque assim ele estará atraindo e conversando melhor com seus potenciais clientes (confeiteiros e cozinheiros que se interessem pelo assunto), como também estará sustentando uma imagem que Ihe confere autoridade para vender tal curso. De forma análoga, aqueles que se autodenominam "empreendedores digitais" o estão fazendo para atingirem clientes que procuram por marketing digital, já que, para esses profissionais, as redes sociais funcionam mais como um meio de conquistar clientes do que um retrato objetivo de seu currículo.

Percebeu-se, ainda, que muitos desses empreendedores digitais iniciaram suas atividades em nichos bem específicos, mas depois de aprender sobre produção, distribuição e venda online acabam sendo requisitados para ensinarem sobre isso e migram para o nicho do marketing digital. Esse foi o caso de Maysa, que iniciou suas atividades dando dicas de maquiagem, Anderson, que começou compartilhando conteúdos sobre teologia e Daniel que começou usando a internet para dar sequência em seu empreendimento físico de estamparia de roupas, etc. Ou seja, esses empreendedores, depois de certo tempo atuando em um determinado nicho, migraram para o nicho do marketing digital, seja produzindo infoprodutos ou sendo afiliados, passando a divulgar conteúdo relacionados às habilidades do empreendedor digital (venda, distribuição e produção), como, por exemplo, Copywriting (Hugo), E-mail marketing (Jaqueline), como vender como afiliado usando o youtube (Daniel), ferramentas para blogueiros (Enzo), etc.

A tabela 4 resume o principal produto que os sujeitos de pesquisa disseram estar comercializando, no momento das entrevistas. 
6

Tabela 7 - Nicho de atuação dos entrevistados no momento da entrevista

\begin{tabular}{|c|c|l|}
\hline Participante & $\begin{array}{l}\text { Nome } \\
\text { Fictício }\end{array}$ & $\begin{array}{l}\text { Principal produto ou serviço comercializado na época da } \\
\text { entrevista }\end{array}$ \\
\hline 1 & Anderson & Gestão de tráfego pago \\
\hline 2 & Bráulio & Curso sobre como ganhar dinheiro na internet \\
\hline 3 & Carlos & Curso de como monetizar com youtube \\
\hline 4 & Daniel & $\begin{array}{l}\text { Curso sobre como ganhar dinheiro como afiliado utilizando o } \\
\text { YouTube }\end{array}$ \\
\hline 5 & Enzo & Venda de ferramentas e softwares para blogueiros \\
\hline 6 & Flávio & Blogs \\
\hline 7 & Gabriel & $\begin{array}{l}\text { Curso sobre como monetizar com Google Adsense e como } \\
\text { criar infoprodutos }\end{array}$ \\
\hline 8 & Hugo & Cursos de Copywriting \\
\hline 9 & lago & Curso de como ganhar dinheiro na internet \\
\hline 10 & Jaqueline & Curso de como ganhar dinheiro na internet como Afiliado \\
\hline 11 & Karine & Consultoria sobre como crescer o Instagram \\
\hline 12 & Laura & $\begin{array}{l}\text { Curso sobre como ganhar dinheiro na internet como Afiliado } \\
\text { usando Instagram }\end{array}$ \\
\hline 13 & Maysa & Mentoria emocional para Empreendedores \\
\hline
\end{tabular}

Fonte: Elaborado pelo autor

A observação da tabela revela que dois participantes destoam do restante. Flávio é um entrevistado que se autodenomina empreendedor digital e não blogueiro, apesar de sua área de atuação ser monetizar a partir das visitações que ele recebe em seus diversos blogs. Como ele gerencia uma rede de seis blogs próprios, ele se autodenomina empreendedor digital e se enquadra nos critérios de pesquisa, ainda que sua atuação se dê de forma diferente da dos demais. Já Maysa oferta serviços de mentoria emocional para pessoas que querem empreender, em sessões individuais de atendimento online na qual ela direciona a trajetória de seus mentorados.

Todos os outros 11 participantes vendem cursos que ensinam uma ou mais habilidades do empreendedor digital, isto é, são empreendedores digitais que vendem cursos ou serviços para outros empreendedores digitais ou para pessoas interessadas em se tornar empreendedoras digitais. Uma possível explicação para esse fenômeno reside no fato de que a retórica empreendedora como heroica e única (COSTA et al., 2002), combinada com a retórica de que é fácil começar um negócio online (KUESTER et al., 2018; GUTHRIE, 2014; ACCENTURE, 2014) é tão sedutora que faz com que muitos indivíduos não só abracem a ideia de ser um empreendedor digital, como também faz com que eles queiram ensinar e influenciar outros indivíduos a serem empreendedores digitais também. A criação do marketing de afiliados e de plataformas que facilitam a monetização online e afiliação em produtos, tais como Hotmart, Eduzz, Monetizze, Lomadee, etc. tornam os discursos e as promessas mais críveis, pois são 
portais que usam da transparência, fáceis de usar e manejar e possuem muitas pessoas e produtos cadastrados, dando a prova social necessária para passar credibilidade. Ou seja, o momento atual onde o ecossistema digital passou a ser mais acessível e mais completo (NAMBISAM, 2017), somado ao aumento do desemprego (ACCENTURE, 2014, e ao fato de as pessoas estarem cada vez mais motivadas pelos seus objetivos próprios (SULLIVAN E BARUCH, 2009) contribuem para que mais pessoas passem a buscar por empreendedorismo digital. Na medida em que essa procura aumenta, mais pessoas ofertam esse tipo de conteúdo, formando um grande grupo de indivíduos se autodenominando empreendedor digital de forma a difundir essa ocupação profissional.

\subsection{Marcos objetivos da carreira dos empreendedores digitais.}

Neste tópico serão apontados os acontecimentos e marcos objetivos que os empreendedores digitais relataram ter contribuído para que a carreira nessa área fosse possível. Para apresentar esses marcos, o presente tópico foi estruturado em quatro subitens. Esses subitens foram criados com base nos relatos comuns sobre os principais acontecimentos que marcaram as trajetórias dos empreendedores digitais entrevistados. Ou seja, muitos entrevistados relataram ter passado por experiências objetivas e sequenciais que fizeram enorme diferença na construção de suas carreiras. O marco inicial, em muitas trajetórias, foi a busca, na internet, por meios de como ganhar dinheiro na internet. O segundo marco foi a compra de algum curso sobre empreendedorismo digital ofertado por um empreendedor digital. Na sequência, eles consolidam suas empreitadas empreendedoras ao realizarem sua primeira venda online e, por fim, a participação em congressos e fóruns presenciais os ajuda a se manterem nessa carreira. A seguir cada um desses acontecimentos são analisados.

\subsubsection{Pesquisa sobre "como ganhar dinheiro na internet"}

Primeiramente merece destaque o fato de vários entrevistados, principalmente aqueles que têm maior tempo de atuação nesta carreira, pontuarem sobre a importância de se pesquisar no Google "como ganhar dinheiro na internet?". Conforme as falas seguintes ilustram, esse foi o início de uma busca por uma nova área de atuação profissional, sendo um marco objetivo importante para suas carreiras. 
"E aí usei aquela célebre frase que todo mundo procura no Google: "como ganhar dinheiro na internet". É a primeira coisa que a gente faz e eu encontrei um e-book na época." (Anderson).

"Então a próxima pesquisa foi a tradicional praticamente que leva 99,9\% dos empreendedores digitais (...) eu fui pro google pesquisar "como ganhar dinheiro na internet' isso era 2011." (Carlos).

"eu acho que a pergunta, né, que mais existe hoje, principalmente agora nessa época de confinamento, é como ganhar dinheiro na internet, como ganhar dinheiro em casa... Então eu sempre fiz isso muito. Muito mesmo. Entrei em algumas furadas aí, né?" (Daniel).

"Em 2008 (...) tudo que tu perguntasse pro Google ele respondia, deixa eu ver aqui, 'como ganhar dinheiro na internet', aquela perguntinha... Que hoje é muito mais manjada do que era antigamente... E daí veio lá as respostas, né? Naquele tempo tinha 3, sendo que 2 era confiável. Naquela época... Eu já sou já um dinossauro, digamos, um dinossauro velho já nesse mercado, mas tinha pessoas que são mais velhas ainda" (Enzo).

Essa busca pode ser entendida, em grande medida, como reflexo de um contexto que combina aumento do desemprego (ACCENTURE, 2014), mudanças na organização do trabalho (SAVICKAS, 2012) e crescente tendência de digitalização (BARBOSA, 2020), que configura um ambiente que influencia um maior número de indivíduos a buscarem maneiras de ganhar suas vidas através de atividades desenvolvidas na internet. Nesse sentido, conforme o modelo do Life Design (Savickas et al., 2009) sugere, o contexto parece ter sido decisivo para que esses indivíduos optassem por iniciar essa nova carreira.

\subsubsection{Ser cliente digital antes de se tornar empreendedor digital}

Outro fator objetivo que apareceu em um número considerável de entrevistas foi que somente depois de terem feito um curso sobre como ganhar dinheiro na internet, sobre marketing de afiliados ou sobre alguma habilidade do empreendedor digital é que os empreendedores digitais acreditaram na possibilidade de essa ser uma opção profissional. Foi depois desse marco que eles iniciaram suas trajetórias empreendedoras. As falas abaixo mostram isso:

"Eu adquiri um produto do Dani Edson [infoprodutor conhecido], que foi o primeiro produto que eu comecei a ter a visão, ter a visão que era possível, trabalhar pela internet." (Enzo). 
"E ai eu vi que o Fabio [infoprodutor] tinha um curso gratuito. Não tinha grana pra comprar curso (...) e ai eu cara comecei a assistir o curso do Fabio. (...) Ai comecei a desenvolver [meu] negócio. Comecei com um blog." (Carlos).

\begin{abstract}
"Nesse período, em 2018, eu comecei a estudar sobre marketing digital, porque eu precisava melhorar o meu posicionamento na internet (...) pra poder estar divulgando meu trabalho, pra poder estar atraindo novos clientes... Então em 2018 eu fiz o meu primeiro investimento que foi um curso do Érico Rocha [infoprodutor conhecido no mercado], chamado Fórmula $6 \mathrm{em} \mathrm{7,} \mathrm{que} \mathrm{são} 6$ dígitos em 7 dias. [Ele ensina a ganhar]100 mil reais em 7 dias." (Laura)

"Quando eu iniciei eu tinha aprendido apenas o mercado de afiliados, né, que era promover produtos e ganhar comissão em troca. Só que aí no curso que eu fiz o mentor ensinou pra gente assim que tinha como a gente ganhar dinheiro dessa forma (...). Aí ele ensinou a importância de ter um blog, e, se for possível, ter um canal no YouTube". (lago)
\end{abstract}

"Em 2011 foi quando eu comecei a pesquisar sobre esse assunto na internet... Encontrei, na época, um curso, e até comprei." (Jaqueline)

Em outro momento da entrevista Jaqueline conta de novo como foi o processo de ter comprado um curso, o que evidencia a importância desse fato. Eis a sua fala:

"E aí pesquisando bastante eu encontrei na época um curso lá que era bem completo, comprei esse curso, falei, "cara, agora eu não posso mais me dar o luxo, vou ter que cair pra dentro disso daqui e aplicar", porque eu preciso ter alguma forma de ganhar dinheiro sem precisar sair de casa." (Jaqueline).

Esse aspecto objetivo, presente na trajetória na maioria dos empreendedores digitais entrevistados, reforça o impacto da influência social na construção dessa carreira. Essa perspectiva de relacionamento existente no empreendedorismo digital cria um espaço compartilhado onde a compreensão, o conhecimento, bem como várias perspectivas são criadas e recriadas (BLUSTEIN et al., 2004). Ou seja, a carreira do empreendedor digital é criada e recriada por meio da interação entre indivíduos que se relacionam através da internet. Em linha com as considerações de Savickas et al. (2009) de que o indivíduo e seu ecossistema "formam uma entidade complexa e dinâmica, resultando numa adaptação e auto-organização ao longo do tempo" (p.242), os relatos obtidos sugerem que, conforme mais empreendedores digitais foram entrando nesse mercado e divulgando cada vez mais cursos e e-books sobre empreendedorismo digital, mais indivíduos foram impactados pela retórica que valoriza o empreendedorismo (COSTA et al., 2002) e a ideia de fácil geração de renda que caracteriza o empreendedorismo digital (DY et al., 2017) retroalimentando o interesse e a procura pela carreira de empreendedor digital.

Outro aspecto que reforça esse entendimento foi abordado ao se analisar o nicho de atuação dos empreendedores digitais entrevistados. Aqueles indivíduos que fizeram 
uma busca ativa de "como ganhar dinheiro na internet" são indivíduos que atuam há mais tempo na área. Por outro lado, alguns dos entrevistados que atuam há menos tempo foram impactados passivamente por publicidade dos empreendedores digitais mais antigos. Os resultados indicam que entre 2006 e 2010, os indivíduos precisavam buscar ativamente por formas de ganhar dinheiro na internet. Depois disso, conforme mais empreendedores digitais passaram a aprimorar sua forma de divulgação, venda e marketing digital, indivíduos com interesse potencial em marketing digital e empreendedorismo digital passaram a ser abordados diretamente através das redes sociais, e-mail ou sites. Portanto, os relatos indicam que o ecossistema de empreendedorismo digital individual foi sendo construído e reconstruído socialmente, na medida que, ao longo do tempo, mais indivíduos passaram a "fingir até conseguir" triunfar dentro do empreendedorismo digital (STANDING e MATTSSON, 2018).

\subsubsection{Realização da primeira venda}

Conforme anteriormente ressaltado, o primeiro movimento feito por muitos entrevistados na direção de se tornarem empreendedores digitais foi pesquisar como ganhar dinheiro na internet. Se esse foi o marco zero de várias trajetórias empreendedoras, o passo decisivo no processo de construção da nova carreira foi a realização da primeira venda online, pois foi a partir desse momento que eles perceberam que realmente seria viável ganhar o dinheiro prometido nos cursos. Conforme ilustram as falas de Jacqueline, que se dedica a vender cursos sobre como ser remunerado na internet aderindo ao marketing de afiliados e Carlos, que ensina como ser remunerado na internet usando o Youtube, tal fato mostrou, de forma concreta, que era possível fazer da nova atividade uma forma de ganhar a vida:

"Eu consegui finalmente fazer uma venda aí de 65 reais, que eu lembro até hoje, né, eu tava lá lavando a louça, e aí uma hora da tarde meu celular apitou e eu fui lá ver, eu tinha feito a primeira venda. A primeira venda a gente nunca esquece, porque é quando cai a ficha de que é real esse negócio, ele realmente funciona, então eu só preciso me dedicar mais pro negócio continuar fluindo e continuar acelerando. E, aí no começo de 2014, eu já estava faturando mais do que qualquer outro emprego tradicional que eu tivesse trabalhado em toda a minha existência, tava conseguindo dar uma vida melhor pra minha família, pra minha mãe e tudo mais... E dali pra frente eu não parei mais, cara, comecei a investir em conhecimento, comecei a trabalhar bastante forte como afiliada de produtos digitais."(Jacqueline)

"Ai cara [eu fiquei] 9 meses escrevendo artigos quase que diariamente e (...) nove meses depois a primeira chave virou, que é o mosquitinho que pica a pessoa que começa a trabalhar na internet que é o mosquitinho da primeira venda. Quando você faz a primeira venda você começa a perceber que tudo aquilo faz sentido. Até então você acha que as pessoas estão mentindo, acha que todo mundo tá te querendo passar a perna que as 
pessoas estão querendo ganhar o seu dinheiro. Mas quando aparece venda realizada, você recebe a msg de venda realizada e e-mail e dali a 30 dias depois você pode sacar aquele dinheiro, ai as coisas começam a ficar diferente". (Carlos)

Já para Bráulio foi a primeira venda de valor mais elevado que motivou a dedicação integral ao empreendedorismo digital:

"Eu lembro quando eu fiz a primeira venda grande, foi em 2011. Cara, foi 350 reais. Em 2011, a minha primeira venda grande. E aí eu cheguei e mostrei pra minha mulher assim, ela não acreditava." (Bráulio)

Apesar de Savickas et al. (2009) ressaltarem que os indivíduos tem narrativas singulares e complexas de suas trajetórias de carreiras, observou-se que a primeira venda foi a grande impulsionadora da dedicação integral de todos os entrevistados a carreira de empreendedor digital. A partir desse marco eles começam a se ver e a se definir como empreendedores digitais.

\subsubsection{Participação em congressos ou eventos presenciais}

Alguns entrevistados relataram que, após a participação em eventos presenciais e congressos sobre marketing digital, empreendedorismo digital ou marketing de afiliados, eles tangibilizaram algo que eles só viam através das telas e, a partir deste momento, passaram a acreditar mais na possibilidade de se tornarem empreendedores digitais ou, pelo menos, não desistirem de atuar nessa área. Os relatos de Hugo e Flávio exemplificam o exposto.

"O evento [de empreendedorismo] aconteceria em São Paulo, e eu sou do Rio de Janeiro, e eu não tinha dinheiro pra ir pro evento. Eu já tinha pagado o evento, mas a passagem, a hospedagem, eu não tinha dinheiro pra nada disso. E aí eu... Peguei dinheiro emprestado com a minha sogra na época, e paguei uma passagem de ônibus no pior horário, a mais barata, e paguei a ida e a volta(...), como eu não tinha dinheiro pra hospedagem, precisei fazer esse bate e volta. (...) E aí eu fui, como eu não tinha dinheiro pra pagar a hospedagem e etc, eu fui e tomei banho na rodoviária, dormi na rodoviária, pra poder participar daquele evento. Eu considero esse ponto da história bastante importante porque, cara, ali eu poderia ter desistido. (...) eu fui pra esse evento, e lá no evento encontrei com vários amigos, respirei o mesmo ar que esses milionários." (Hugo)

"Quando a gente vai pra evento encontra todo mundo... Tipo assim, tem muito esse costume de ir aos eventos, né? Eu já palestrei em alguns eventos também... Ano passado eu palestrei no Search Masters, que é o evento mais importante de marketing de busca do Google, essas coisas assim..." (Flávio) 
Já para Carlos, a participação num evento presencial se deu de maneira quase heróica e a realização desse feito acabou por fazer a diferença na sua carreira de empreendedor digital:

"Em 2017 (...) eu fui no [evento] Afiliados Brasil. Eu ganhei o ingresso no pior ano financeiro da minha vida. (...) E eu digo: "cara eu ganhei o ingresso, sempre quis participar, mas como vou ir, velho? Não tenho grana pra passagem". Eu moro em Pelotas e eu tava em Pedro Osório e o evento era em São Paulo, cara, como eu vou fazer pra ir? Agora eu já ganhei o ingresso, tenho que ir. Comecei a entrar em contato com caminhoneiros, amigos meus, consegui um caminhão indo para São Paulo acho que 2 ou 3 dias antes do evento. Peguei carona com esse cara pra ir. Falei com um amigo meu lá de São Paulo, (...). ele me deu a hospedagem, fiquei os 3 dias na casa dele, foi fantástico, foi surreal." (Carlos).

Para Gabriel, a sua carreira de empreendedor digital tomou outra proporção após a participação num evento presencial pelos conhecimentos adquiridos em tal ocasião:

"Foi o primeiro evento que eu fui fora do Espírito Santo, de marketing, né? Aí fui lá para São Paulo, (...). Foi muito legal, foi um evento, assim, que começou a mudar, (...) cara, eu vi que era possível... Refiz muita coisa, aprendi muita coisa lá, não trabalhava ainda com e-mail marketing pra vender com um funil de vendas, aí comecei a estudar isso, e comecei a me preparar para lançar meu primeiro treinamento em vídeo." (Gabriel)

Assim, percebe-se que a participação em congressos e eventos presenciais adquiriu um simbolismo importante para os empreendedores digitais, seja porque a participação nesses eventos requereu deles uma atitude heroica ou a superação de desafios, como conseguir dinheiro para transporte, por exemplo, seja porque a interação com indivíduos que atuam da mesma forma no mercado os fez repensar e ressignificar suas próprias maneiras de atuarem. Em outras palavras, considerando que a construção de sentidos se dá por meio das interações sociais, a participação em eventos presenciais força-os a intensificar suas interações sociais o que contribui, portanto, para que os indivíduos vejam cada vez mais sentido em se autointitularem empreendedores digitais.

\subsection{Motivações para a carreira de empreendedor digital}

Neste tópico serão explorados os elementos narrativos identificados que ajudaram a dar sentido subjetivo à trajetória percorrida pelos empreendedores digitais. Primeiramente serão analisadas as principais motivações que levaram os entrevistados a escolherem a carreira de empreendedor digital. Na sequência serão analisados, também, a percepção dos entrevistados sobre o sucesso na carreira. 
Vale ressaltar que as análises foram elaboradas levando em consideração que, para se compreender uma carreira, segundo o modelo do Life Design (Savickas et al., 2009), é preciso fundamentar-se em cinco pressupostos acerca das pessoas e das suas vidas no trabalho: (I) Analisar as possibilidades associadas ao contexto ao invés de analisar os traços de personalidades individuais; (II) analisar as estratégias de sobrevivência e a dinâmica de enfrentamento ao invés de analisar os conhecimentos adquiridos; (III) Considerar que as aptidões e interesses individuais seguem uma progressão não-linear e podem mudar com relativa rapidez; (IV) Considerar que existem realidades subjetivas múltiplas e que as relações sociais têm evoluído de modo que indivíduos estão continuamente se construindo e reconstruindo; (V) Evitar o reducionismo de análise a uma única variável e considerar que indivíduos tem narrativas singulares e complexas.

\subsubsection{Insatisfação com o(s) trabalho(s) anterior (es)}

Para alguns entrevistados, a insatisfação com o trabalho anteriormente exercido se deu pela ausência de liberdade de atuação ou escassez de tempo, conforme relatado por Hugo e Karine:

"Uma das coisas que me tirava o sono na época que eu estava como diretor na rádio era a ausência de liberdade e a escassez de tempo, eu não tinha tempo pra quase nada. $E$ eu não tinha também muita liberdade... até mesmo criativa, apesar de ser lá o diretor, ser um dos líderes, eu... Eu tinha uma certa limitação. Então eu queria trabalhar de casa, no home office, fazer meu próprio horário, queria viajar, etc... Então, o que me motivou a empreender online foi isso." (Hugo)

"Dentro do escritório eu ficava muito presa, então eu vi uma possibilidade de eu ter horários mais flexíveis, tanto pra "mim" trabalhar, pra "mim" poder estudar outras coisas, fazer outras coisas, então a primeira coisa que me chamou atenção foi essa flexibilidade. De eu poder trabalhar de casa, de eu poder sair mais pra viajar, porque às vezes eu ficava muito presa de não conseguir fazer as coisas que eu queria. Então esse foi um ponto. E outro que acabou chamando minha atenção ao longo do tempo também foi questão de [possibilidade de] faturamento, que dá pra tirar muito mais do que na área que eu me formei." (Karine)

Para Flávio, o que o deixou insatisfeito com seu trabalho anterior foi uma combinação de inadequação com a hierarquia corporativa e o salário considerado baixo:

"Te dizer que financeiramente [ser empreendedor digital] me dá mais resultado do que quando eu estava trabalhando com T.I. porque... Talvez, para eu ter o resultado que eu tenho, eu teria que estar no cargo de gerente lá, e isso não é fácil, tipo... Você tem que, digamos assim, bajular as pessoas certas, não é só trabalhar bem (...), não é só fazer o 
trabalho direito, então, pra mim [o empreendedorismo digital] foi muito bom, hoje eu estou bem satisfeito." (Flávio)

Já para Enzo, era um incomodo trabalhar em um emprego de baixa remuneração e ser funcionário de alguém:

"Eu era um frentista, só que eu não... não era contente com, né? Tipo... A parte literalmente de ser empregado de alguém, eu não gostava muito dessa parte, de ser empregado de alguém, uma por causa do salário, outra por causa de... De vários fatores, né?" (Enzo)

Por sua vez, para Jaqueline, era difícil conciliar a rotina corporativa com a maternidade:

"Então eu pegava basicamente um carro, colocava televisão, colocava tudo que uma criança podia ter pra brincar, botava ele lá dentro, levava ele pra escola, consegui uma vaga na escola próxima ao trabalho, trabalhava, quando chegava 12h, eu buscava ele na escola ele ficava na oficina comigo até 19h. E aí, cara, chegou um ponto que eu pensei, putz, isso não é vida de criança, né?" (Jaqueline)

Portanto, seja por inadequação à hierarquia corporativa, insatisfação com o salário baixo, ausência de liberdade, escassez de tempo e rotinas desgastantes, a insatisfação com o emprego anterior foi um dos principais motivos apontados pelos empreendedores digitais como impulsionadores pela busca de uma carreira digital.

\subsubsection{Ambição em ganhar dinheiro "sem sair de casa"}

A insatisfação com trabalho anterior combinou-se, em muitos casos, com a possibilidade de ganhos altos provenientes no empreendedorismo online:

"Só ontem eu faturei mais de mil reais em um dia... Em um dia eu faturei o que muitas pessoas às vezes trabalham 30 dias aí pegando ônibus, indo em pé, tendo que ouvir desaforo de chefe, pra receber mil reais em 30 dias, e eu faço isso em um dia. Teve dia que eu fiz 1600, teve dia que eu fiz 1500 em um dia. Então realmente é um mercado que funciona, mas que infelizmente muitas pessoas ainda não sabem usá-lo ao seu favor". (Laura)

"Tu tem a liberdade de poder ter uma renda acima da média dos padrões brasileiros (...) e ganhar dinheiro enquanto tá dormindo. Tem muita gente que... A gente fala assim: 'ganhar dinheiro quando tá dormindo?', e parece uma coisa de outro mundo, né?" (Bráulio)

Para Jaqueline, uma das coisas que a atraiu para o empreendedorismo digital não foi tanto a ambição de ganhar muito dinheiro, mas sim a possibilidade de ter liberdade financeira e ganhar dinheiro em casa. 
"Porque eu preciso ter alguma forma de ganhar dinheiro sem precisar sair de casa. Eu preciso disso, eu preciso ter a minha liberdade financeira." (Jaqueline)

\subsubsection{Desejo de empreender com baixos risco e investimentos iniciais}

Outro fato que motivou os empreendedores digitais a seguirem essa carreira foi a facilidade em ter um negócio próprio que a internet propiciou. Para Alexandre, Bráulio e Jaqueline, o empreendedorismo digital apareceu como possibilidade de realizar o sonho de ser empreendedor com baixo investimento inicial e baixo risco:

"Eu sempre tive essa mentalidade. Vou até arrumar um emprego registrado agora porque eu preciso, eu tenho uma família para sustentar, mas eu não vou ficar nesse emprego. Eu vou empreender. Eu vou levantar uma grana e vou dar a volta por cima." (Alexandre)

"Trabalhei de empregado em restaurante, trabalhei em frigorífico, trabalhei fazendo bicos, né? Capinar... Já capinei pátio, já pintei colégio... E aí o que que acontece? Eu tinha um sonho de ter meu negócio próprio, sempre tive, desde lá dos meus 16, 17 anos, eu tinha um sonho, eu não sabia o que que ia ser, não sabia. Eu sabia que eu ia ter [meu próprio negócio].(...) E aqui eu quero fazer uma observação, quando a gente fala assim, "ah, eu tive que dar um passo pra trás pra trabalhar como funcionário", eu não estou dizendo que trabalhar como funcionário, como empregado é algo pejorativo (...), não! Eu estou falando por mim, entendeu?" (Bráulio)

"Eu quero ter um negócio ou uma rendinha extra? Não, eu preciso de um negócio. Todo negócio requer um investimento. Se eu for vender pipoca na rua eu preciso comprar o carrinho, o saquinho, o jaleco, o gás, pagar o imposto... Então eu preciso ter um negócio. Só que na internet o meu investimento e meu risco é muito menor que no físico. Então por que eu não vou investir no meu conhecimento para que eu possa criar um negócio que tenha mais direcionamento?" (Jaqueline)

Portanto, os relatos obtidos corroboram o entendimento de que os empreendimentos digitais demandam poucos recursos para sua criação e operação e que a ampla adoção das tecnologias de informação e comunicação e a internet móvel proporcionaram uma noção de aumento das oportunidades empreendedora por mídias digitais (KRAUS et al., 2018, MASON; CARTER; TAGG, 2011, STEININGER, 2018). Tal fato parece vir contribuindo para motivar cada vez mais pessoas a empreenderem online.

\subsubsection{Monetização de um hobby}

Alguns empreendedores digitais começaram suas atividades como hobbies. Gabriel e Flávio, por exemplo, disseram gostar de escrever e, por isso, criaram um blog. 
Com o tempo eles foram amadurecendo a ideia de fazer de seu hobby um meio de ganhar a vida:

"E eu comecei a ter visitas no blog e aí comecei a fazer uns textos melhores, tal... E começou a ter muita visita. E aí eu resolvi tentar... Falei, "pô, deve ter alguma maneira de rentabilizar isso "." (Gabriel)

"Em 2010 eu botei um blog no ar, que era um hobby mesmo assim, eu gostava de escrever, era um blog de humor (...), e comecei a conhecer um pessoal que vivia de internet (...). E eu falava, 'caramba, né? O cara vive disso'” (Flávio)

Para Laura, era um hobby ajudar as amigas maquiadoras, sendo modelo para elas, até que ela viu a oportunidade de cobrar por este serviço e usar a internet como forma de divulgar o serviço:

"E meu marido foi e falou pra mim assim, "ah, por que que você não começa a cobrar pra ser modelo de maquiagem?". Eu olhei pra ele e falei, "você é louco, não conheço ninguém que faz isso, isso não é profissão. Eu que tinha que tá pagando a maquiadora, porque ela tá gastando material, me maquiando e tudo mais", mas decidimos tentar, porque a gente estava desempregado, não tinha de onde tirar dinheiro, falei então vamos tentar começar a cobrar pra ser modelo de maquiagem. E eu utilizei o Instagram, que era o que eu tinha ao meu favor na época, na verdade eu utilizo o Instagram até hoje ao meu favor, hoje eu vivo só de Instagram, minha renda vem do Instagram... E aí eu comecei a utilizar o Instagram pra poder divulgar meu trabalho como modelo de maquiagem e penteado, mesmo sem conhecer ninguém que trabalhava com isso" (Laura)

Após estudar sobre marketing digital para monetizar um hobby, Laura acabou migrando para o nicho de marketing digital, mas a motivação inicial se deu não só pela necessidade financeira, mas pela possibilidade de unir um hobby a uma ocupação profissional.

Em linha com os achados de Nassif et al. (2009) em pesquisa acerca dos microempreendedores brasileiros, foi possível notar, nos relatos, que não há apenas um único aspecto responsável por fazer o indivíduo decidir por seguir a carreira como empreendedor digital. Conforme ressaltam os referidos autores, "não é apenas um fator isolado que determina a ação de empreender e sim um conjunto de fatores que estimulam o fenômeno e esses foram identificados, tais como: reações às situações adversas; desejo de crescimento; acreditar no seu próprio potencial e conhecimento; ambiente familiar; busca do sonho; desejo de trabalhar por conta própria e a percepção de oportunidade para empreender" (Nassif et al., 2009, p.165). Contudo, diferentemente do citado estudo, o empreendedorismo digital difere do tradicional e, portanto, as motivações são um pouco distintas, sendo as principais: a insatisfação com trabalhos anteriores; a ambição em ganhar dinheiro sem sair de casa; monetização de um hobby e o desejo em empreender com baixo risco e baixo investimento inicial. 


\subsubsection{Sucesso na carreira de empreendedor digital}

Quando perguntados sobre se se consideram bem-sucedidos na carreira, todos, sem exceção, responderam que sim. Considerando que as narrativas são meios que os indivíduos usam para elaborar suas identidades psicossociais, aceitar mudanças e fazer escolhas (CARDOSO; SAVICKAS; GONÇALVES, 2019), e o nicho de atuação dos entrevistados é vender o marketing digital como um meio para ganhar a vida, argumenta-se que era esperado que as narrativas dos entrevistados contivessem registros positivos sobre a atuação como empreendedores digitais. Afinal, para venderem cursos, e-books e mentorias que ensinam como adquirir as habilidades do empreendedor digital, esses empreendedores precisam continuar propagando o discurso de que é possível ganhar dinheiro na internet e que tal carreira é uma maneira de tornar-se bem-sucedido. Assim, é possível considerar que suas narrativas estão retroalimentando narrativas semelhantes às que eles escutaram ao começarem suas carreiras. Ou seja, faz parte do negócio de quem vende produtos de marketing digital narrar suas carreiras de um ponto de vista de sucesso. Mais uma vez, o método escolhido na seleção dos sujeitos acaba apontando para essa direção, pois se fossem escolhidos sujeitos que tentaram a carreira online e não conseguiram obter renda nesse meio, certamente o discurso seria diferente.

A partir dos relatos dos entrevistados, pode-se considerar que o sucesso subjetivo para o empreendedor digital compreende, pelo menos, quatro fatores principais. $O$ primeiro é a percepção de se trabalhar com algo que os deixa mais felizes e preenche um senso de propósito. A fala de Jaqueline ilustra esse ponto:

"Eu acho que o bem-sucedido não é só aquele que ganha muita grana, porque muitas vezes a pessoa ganha muita grana, mas odeia o que faz. E isso não é sucesso, na minha opinião. O sucesso é quando você encontra a tua missão, teu propósito, o que você quer compartilhar com o mundo, você consegue ajudar pessoas com isso, e ao mesmo tempo você é bem pago por isso." (Jaqueline)

O segundo é a percepção de se trabalhar com liberdade de tempo e autonomia de atuação. A fala de Flávio mostra essa percepção:

"Acho que eu estou muito mais feliz do que se eu tivesse, por exemplo, trabalhando em T.I., que é o que ia trabalhar antes, sacou? Acredito que eu estou ganhando melhor e trabalhando com menos estresse, porque eu não tenho um chefe aqui no meu cangote, eu mesmo que defino meus horários, então, tipo, isso é importante" (Flávio) 
A sensação de que está ajudando pessoas e contribuindo positivamente para a vida de outro alguém é outro aspecto que reforça a percepção de sucesso, como ilustra a fala de Hugo:

"Fora o fato dos alunos e empreendedores que eu já ajudei, né? Então são milhares de negócios que foram ajudados aí pela minha agência e pelo meu negócio, milhares de empreendedores também, então nesses sentidos, eu acredito que sim, a gente pode falar que a carreira foi bem-sucedida. Está sendo, né?" (Hugo)

Já para Gabriel, o que define o sucesso nesta carreira é a atuação consistente numa área, sem ter dúvidas quanto à sua ocupação profissional:

"Eu, profissionalmente, eu me considero bem-sucedido e realizado. Estou há 12 anos nisso, tem 9 anos que eu saí do meu emprego público, nunca mais depois que eu saí eu pensei em fazer um outro concurso público ou ir trabalhar novamente para alguém. Nunca... Nunca nem cogitei, então me considero bem-sucedido sim." (Gabriel)

Além disso, para alguns entrevistados, o sucesso também é expresso por marcos objetivos. Gabriel, por exemplo, apontou um marco objetivo como parte de seu sucesso:

"Porque era aquilo: "Ah, meu objetivo é ter 5 mil visitas [no site] por dia", ah eu tive 5 mil, eu tive sucesso. Só que, a gente não pode sentar nisso aí. A gente tem que traçar outro planejamento, outro projeto pra fazer." (Gabriel)

Hugo foi outro empreendedor que ilustrou marcos objetivos como indicadores de seu sucesso:

"Então, assim, essa questão do sucesso eu acredito que esbarra muito com o objetivo do empreendedor. Eu acredito que a minha carreira seja bem-sucedida, justamente porque eu alcancei meus objetivos. Um dos meus objetivos era escrever livros que se tornassem best-sellers na área de marketing. Então, o meu primeiro objetivo de carreira em 2013, eu já coloquei isso lá. Então, hoje eu tenho 4 best-sellers, dos 8 livros que eu publiquei. Então eu acredito que isso, de certa forma, esbarra com essa questão do sucesso, de ser bem-sucedido. (Hugo)

Portanto, o cumprimento de metas e objetivos traçados previamente e a realização de feitos de tempos em tempos os fazem se sentirem realizados. Na medida em que vão realizando feitos e conquistando algumas métricas que eles mesmo estabelecem em comparação com outros empreendedores digitais os quais eles têm como referência, vão se sentindo realizados e construindo a ideia de sucesso na carreira. Outra evidência de que a percepção de sucesso é moldada comparando-se com outros indivíduos está presente na fala de Laura:

"Quando uma pessoa ela é muito bem-sucedida, quando uma pessoa ela tá ganhando muito dinheiro, eu me faço essa pergunta, o que essa pessoa fez pra chegar onde ela tá 
hoje? Qual foi o caminho que ela trilhou? Qual é o posicionamento dela? Sabe? Então, tudo isso, eu sou muito observadora, eu vou lá, eu vejo, eu analiso, e adapto aquilo pro meu jeito, pra minha essência, pro meu estilo de vida." (Laura)

Do ponto de vista construcionista, Blustein et al. (2004) explica que o ambiente social influencia o processo de construção da identidade de um indivíduo dentro de um contexto de trabalho, assim, ao contar as experiências profissionais em uma narrativa, um indivíduo é capaz de encontrar meios apropriados para lidar com os desafios que vêm com o trabalho, desenvolvendo seus conceitos sobre a própria carreira, inclusive o sucesso na carreira.

\subsection{Desafios e barreiras ao empreendedorismo digital}

Savickas et al. (2009) dizem que é preciso focar nas estratégias de sobrevivência e nas dinâmicas de enfrentamento que os indivíduos passam para entender suas carreiras. No caso do empreendedor digital, objeto da presente pesquisa, observou-se que ao superarem adversidades e responderem às críticas de pessoas que se opuseram à sua decisão de se tornarem empreendedores digitais, lograram fortalecer e legitimar suas decisões. As críticas, barreiras e desafios relatados pelos empreendedores digitais foram diversos, sendo os principais:

\subsubsection{Dificuldades em usar a tecnologia}

Essa barreira apareceu principalmente para os profissionais que estão atuando há mais de sete anos na área. Os entrevistados que atuam há menos tempo nesse ramo relatam menos dificuldades relacionados à tecnologia. Uma possível explicação para isso pode ser o fato de que as tecnologias digitais foram evoluindo e se tornando mais fáceis e acessíveis. Porém, os profissionais que atuam há mais tempo como empreendedores digitais relataram algumas dificuldades, como por exemplo:

"No início [2008], pra criar um blog, eu passava às vezes 18 horas pra criar um blog... E, bah, o blog era tudo no código fonte, não era como é hoje, entendeu? Aí se tu mexesse no código fonte e tirasse um parênteses daquilo lá, o blog dava pau, e daí como eu não sabia a linguagem do HTML, né? (...) Tipo, errava um código, meu blog dava pau, eu tinha que ir lá e criar outro blog, passar mais 20 horas em cima, tinha épocas assim que eu estava com o braço destruído, dor nas costas...." (Enzo)

"Bom, eu comecei lá em 2008, fevereiro de 2008... (...) E.eu tava aprendendo muito nessa área de TI, tava fazendo faculdade, começando a estudar aí nessa área, aí eu fui trabalhar em uma empresa, justamente pra poder pegar mais... entender um pouco melhor dessa área de tecnologia, se era isso que eu queria ou não... E eu comecei a encontrar ali várias dificuldades, eu tinha que correr, descobrir o que que eu ia fazer, como que eu ia resolver o problema..." (Gabriel). 
Embora as tecnologias ajudem a compor um ecossistema digital e esse ecossistema desempenhe um papel importante como acelerador do processo empreendedor, há pouca compreensão das interdependências entre os componentes do ecossistema e sua dinâmica evolutiva (MACK e MAYER, 2016).

O que se pode concluir com o presente estudo é que parece existir diferença entre os relatos daqueles que começaram a empreender há muito tempo (antes de 2014) e os que começaram a menos tempo. Os entrevistados que começaram a jornada empreendedora antes de 2014 relataram que era difícil criar um blog, por exemplo, ou mesmo encontrar plataformas de afiliação disponíveis. Esse resultado, por si só, já pode ser considerado relevante, principalmente porque, segundo Nambisan (2017), quanto mais estudos sobre a dinâmica da comunidade ou do ecossistema digital, melhor se torna o entendimento sobre como as tecnologias digitais podem influenciar a natureza e as interações entre os atores para identificar recursos e parceiros do processo empreendedor. Nambisan (2017) acredita que a pesquisa sobre empreendedorismo ignorou parcialmente o impacto das tecnologias digitais e o papel que os usuários e agentes desempenham no empreendedorismo digital.

Além disso, Guthrie (2014) acredita que as tentativas e erros são parte do processo de empreender online. A dificuldade de acesso às tecnologias, plataformas $\mathrm{e}$ ferramentas digitais configurava-se como uma espécie de filtro, onde só passavam aqueles que realmente estavam interessados em seguir a carreira de empreendedor digital. Assim, ao relatarem muitos erros e dificuldades com o uso da tecnologia, os empreendedores digitais mais antigos legitimaram suas decisões de seguirem essa trajetória profissional.

\subsubsection{Comprometimento da saúde}

Em alguns relatos os entrevistados enfatizaram que a trajetória no empreendedorismo digital trouxe danos à saúde de duas naturezas. O primeiro está relacionado à ergonomia, decorrente do trabalho sentado em frente ao computador. $\mathrm{A}$ fala de Enzo ilustra esse problema:

"Tinha épocas assim que eu estava com o braço destruído, dor nas costas...." (Enzo)

Já para lago os danos à saúde são de natureza psicológica, provenientes das criticas familiares e inseguranças atreladas ao processo empreendedor. 
"Então, assim, esse medo de dar errado, de eu não conseguir dar consistência, de eu ter fechado minha loja, ter cancelado todos os clientes fixos que eu tinha, só pra empreender pela internet, por mais que aparentemente eu achei que não ia me afetar, me afetou, então eu desenvolvi depressão, desenvolvi síndrome do pânico"." (lago)

Em ambas as falas, a de Enzo e lago, os danos à saúde são expostos como um problema individual, como uma incapacidade pessoal do entrevistado. Por exemplo, lago relatou seus problemas emocionais aconteceram porque ele não mensurou bem os impactos de sua mudança de vida e carreira. Já para Enzo seus problemas de dores nas costas e no braço aconteceram porque ele não dominava bem a tecnologia e foi preciso retrabalho e um esforço maior do que o "normal" para se alcançar o resultado esperado. Esse mecanismo de culpar-se pode ser entendido como uma estratégia defensiva para se distanciar dos problemas decorrentes da carreira escolhida. Porém, em um dos relatos o entrevistado mencionou com clareza que os danos à saúde formam parte inerente do processo de se empreender online:

\begin{abstract}
"Agora, preciso deixar até um alerta também sobre essa parte de saúde, porque tem esse ônus também, né? Eu fico sentado aqui o dia inteiro... Eu sempre pratiquei bastante esporte, eu estou praticando menos esportes, então tem hora que a gente precisa cuidar, né? Às vezes eu sinto algumas dores que eu não sentia, eu estou com 45 anos de idade, sinto dores às vezes no joelho, um pouco de dor nas costas, à noite quando eu deito dói o braço um pouco, né? Então... Esse é o ônus que é um alerta, né? Talvez seja alguma alerta aí de saúde, eu sou muito novo ainda, pra poder ter essas coisas, então, talvez seja o ônus de toda essa trajetória aí." (Daniel)
\end{abstract}

Sendo assim, existem evidências de que o processo de se empreender online tem seu lado negativo no que diz respeito a saúde física e, principalmente mental, mas esses relatos raramente aparecem nos vídeos e textos vendedores que buscam vender o marketing digital como solução mágica para os tempos modernos.

\title{
4.4.3. Preocupações com ataques de haters e de hackers
}

Conforme aumentam suas exposições na internet, mais sujeitos às críticas eles estão e isso exige inteligência emocional para lidar com aqueles que tem opinião contrária ou simplesmente não simpatizam com o conteúdo compartilhado pelo empreendedor digital. Conforme ressalta Bráulio, os ataques de ódio o fizeram pensar em procurar ajuda policial. Já para Enzo os comentários insultuosos em seus conteúdos o fizeram redobrar a atenção e buscar ferramentas para reduzir os erros que vinham ocasionando os ataques dos internautas: 
"Uma vez o cara me perseguia (...), no webinário, nos artigos do meu blog, nos meus vídeos do YouTube. O cara me xingava de tudo que é palavrão, e eu não sei por que, um hater, né? E aí eu tava pronto pra dar queixa na delegacia, eu ia até Porto Alegre, mas ele parou e aí graças a Deus não foi preciso." (Bráulio)

"Eu comecei a investir no meu blog, e escrevia. Aí tinha muitos (...) haters, né? [eles diziam] 'Ah, esse português horrivel, sem pontuação, e não sei o quê', (...) pauleira em cima de mim. E eu de boa, passava meu texto em dois ou três (...) corretor de português, passava em vários. Aí colocava ali, só pra não vir os haters, né?" (Enzo)

Por sua vez, lago teve problemas com hackers, pois seu blog foi invadido. Tal fato não só fez com que ele experimentasse uma perda em seus ganhos como mancharam a sua imagem.

"2012 meu blog já estava com muita audiência, e eu sofri um ataque [hacker], meu blog tava perfeito, mas pras pessoas que acessavam, aparecia banners e link de pornografia, num blog falando de empreendedorismo digital. E pornografia pro Google é proibido. Então meu blog começou a ser penalizado (...) só que eu não sabia o que era. Então depois de eu ver uma queda brusca nos meus acessos, eu pedi ajuda das pessoas (...), quando foram fazer investigação e descobrirem o que era, foi quase 4 meses depois. Então eu já tinha perdido muita audiência, pessoas que gostavam do meu trabalho, incentivar o filho, vai lá ver o blog lago, ele ensina como trabalhar em casa, vê se você aprende alguma coisa, entrava no meu blog, tinha pornografia. Então perdi o respeito." (lago)

Portanto, ataques de ódio, além de serem uma preocupação de carreira, também se configuram em potencial risco à saúde emocional, tópico discutido anteriormente. Uma vez que o aumento da exposição na internet deixa os empreendedores digitais mais vulneráveis era de se esperar que houvesse uma preocupação por parte dos profissionais terem acompanhamento emocional ou, ao menos, uma consciência sobre a importância de aprimorar a inteligência emocional para lidar com esse lado negativo, porém, os relatos não evidenciaram tal conscientização.

\subsubsection{Falta de apoio e críticas da família e dos amigos}

Dado que a carreira de empreendedor digital é relativamente nova (ANIMYEBOAH et al., 2020), algumas pessoas não a compreendem muito bem. Assim, ao comunicar aos familiares e aos amigos sobre a decisão de se tornarem empreendedores digitais, muitos enfrentaram falta de apoio ou desconfiança. Todavia, argumenta-se que, para superarem esse desafio, os empreendedores digitais incorporam o discurso heroico existente no empreendedorismo e, assim, legitimam suas identidades: 
"Porque se eu ouvisse as pessoas que estavam do meu lado, principalmente... a gente compreende esposa, mãe, irmão diziam "larga isso, isso é coisa de doido. Você é louco. Você tá perdendo dinheiro, olha onde você tá. Vai arrumar um emprego registrado, você tem profissão". (Anderson)

"Naquela época, em 2008, meus irmãos olhavam e falavam, "ai, lá vai o louquinho da internet", né? Tipo eu ficava num quarto ali, trancado, num quarto ali, estudando... Ninguém entendia, né? [Diziam:] "(Enzo) só quer ficar nessa vida, é nerd agora", recebi muita crítica, né? E não entendiam naquela época, né? Então passei por isso aí. Mas o fato é: não desistir. Se não desistir, em algum momento vai virar a chave." (Enzo)

lago parece ter sido o mais afetado pela falta do apoio familiar e de amigos, pois em três momentos distintos da entrevista essa questão veio à tona:

"Eu iniciei sem apoio... Na verdade além de não ter apoio, tinham as pessoas puxando pra trás, "não, não vai dar certo, não vai dar certo"' (lago)

"Quando foi em 2014, eu morava no estado do Tocantins, e eu me mudei pro Rio de Janeiro. Só que eu já fui pro Rio de Janeiro ouvindo isso aqui dos amigos: "cê não vai pra lá, você vai gastar muito"; "isso não vai dar certo"; "você vai voltar com o rabinho entre as pernas"; "olha pra você ver". Então, eu fui, mas na cabeça foi aquilo: "meu Deus, e se não der certo?", então eu tive muita, muita crise de síndrome do pânico, terrível, terrível, terrível." (lago)

"Quando você sai, deixa de ter um emprego, deixa de querer prestar um concurso público, pra você empreender, $90 \%$ praticamente de parentes e amigos não entendem. Então eles vão te pressionar, eles vão falar que vai dar errado, eles vão falar que você é louco... Então se você não tiver a cabeça boa, você roda. Eu quase rodei". (lago)

Os empreendedores digitais que relataram ter sofrido falta de apoio familiar e de amigos já atuam há algum tempo na área (mínimo de sete anos, como é o caso do Enzo e, no máximo, 12 anos, caso do Anderson); os que empreendem há menos tempo relatam menos esse desafio. Uma das explicações possíveis para essa diferença é que a carreira de empreendedor digital vem se tornando cada vez mais conhecida e, na medida em que mais indivíduos passam a atuar profissionalmente dessa maneira, isso passa a ser uma prova social de que é uma atuação possível, fazendo com que parentes e amigos sejam menos críticos quando alguém comunica que seguirá essa carreira.

\subsubsection{Preocupação com charlatanismo e enganações}

Os entrevistados relataram que é comum encontrar na internet indivíduos mal intencionados que tentam vender cursos digitais, e-books e serviços digitais a todo custo. Para tanto, tais indivíduos usam estratégias enganadoras, como mostrar resultados falsos ou contarem mentiras, o que já seria o suficiente para causar desconfiança naqueles que estão buscando meios de seguir essa trajetória profissional. Soma-se a isso o fato que, mesmo o marketing digital honesto, acaba por enaltecer demais a figura do empreendedor como um grande herói global e principal responsável 
pelo crescimento econômico mundial (NASSIF et al., 2007; COSTA et al., 2002). Ainda, as promessas de ganhos financeiros nesse setor são muitas e dizem requerer um baixo investimento e baixo risco (KUESTER et al., 2018; GUTHRIE, 2014; ACCENTURE, 2014). Não obstante, a internet tem sido alvo de queixas por parte dos usuários pela sobrecarga de informação e não por falta delas (SAVICKAS et al., 2009). Assim, num cenário onde existem promessas muito altas, mentiras e enganações e excesso de informação é normal que os empreendedores digitais em começo de carreira sintam-se desconfiados e receosos. As falas abaixo traduzem este sentimento:

"Na época era um pouco fantasioso o que as pessoas prometiam. Você vai abrir um
negócio hoje, amanhã você já está ganhando muito dinheiro não sei o quê... Mas, como
eu já tive uma criação empreendedora, e eu sabia diferenciar o que era furada e o que
que não era. Então antes de eu começar a entrar nesse mercado, eu passei quase 6
meses estudando se tinha base, o que eu realmente iria fazer, que tipo de serviço eu ia
prestar pras pessoas, não só quanto que eu ia ganhar, mas o que eu ia dar em troca pro
cliente." (lago)

"Eu vejo realmente que existem, sim, pessoas hoje dentro da internet que infelizmente se beneficiam da rede digital, e acabam dando golpe, sim, nas pessoas, roubando dinheiro das pessoas, inventando mentiras, pegam resultado que não é dela e falam que é dela, só pra poder enganar as pessoas" (Laura)

"Existe um paradigma na internet de que pra você trabalhar na internet você não precisa investir nada, é rápido e é fácil, só que quando as pessoas chegam nesse mercado, elas percebem que não é assim que acontece, que não é rápido, que não é fácil, que existe um caminho e que exige pelo menos um pequeno investimento ali pra você começar. (Jaqueline)

"Eu comprei um curso e eu achei que ia ganhar 28 mil reais fácil. Eu tive que aprender tantas habilidades, olha, eu precisava de tráfego, eu precisava de design, eu precisava saber falar, eu precisava ter muito conteúdo... (Maysa)

Os empreendedores digitais deste estudo parecem ter superado essas desconfianças atribuindo a culpa das promessas vazias e/ou exageradas à certas pessoas mal-intencionadas e não ao meio ou ao ecossistema digital. Em outras palavras, os empreendedores digitais sabem que os discursos que prometem altos ganhos financeiros com pouco trabalho são, por vezes, fantasiosos e malintencionados, mas não entendem que isso seja um problema da carreira e sim de alguns indivíduos e, contra esse revés, basta estudar e adquirir conhecimento sobre o setor ou se conectar com indivíduos honestos e referenciados.

\subsection{A construção identitária da carreira do empreendedor digital}

O Life Design usa uma perspectiva construcionista social que vê os indivíduos como autores de histórias que podem ser consideradas autobiográficas e que, ao contá- 
las, os levam a refletir sobre os grandes temas de suas vidas (Savickas, 2012). A reflexão sobre esses temas os ajuda a construir e recriar as suas carreiras. Em linha com esse entendimento, a partir da pergunta "como tudo começou?" fez os entrevistados revisitarem seu passado, tendo sido obtidos relatos que vão desde a infância, passando pela relação com os pais, histórias sobre empregos passados, primeiros impulsos empreendedores etc. Tal abordagem permitiu aos entrevistados narrarem suas histórias à sua maneira, de modo que se tornou possível analisar os principais temas que se mostraram presentes na construção identitária dos empreendedores digitais.

Além disso, haja vista as idades diferentes, formações variadas e tempo de atuação distintos, pode-se dizer que os empreendedores digitais retratam o exposto por Savickas et al (2009, p.243), quando afirmam que "hoje, pelo menos nas sociedades ocidentais, assistimos a uma crescente diversidade de realidades individuais, distantes das trajetórias tradicionais. Em todas as idades, as pessoas retornam à escola, procuram formação, perdem os seus empregos e divorciam-se, sem perder, necessariamente, o reconhecimento social. A coexistência de identidades e realidades subjetivas múltiplas parece, desta maneira, ser uma consequência natural destas evoluções sociais." Assim sendo, os relatos obtidos constroem diferentes retratos do que significa ser um empreendedor digital.

Considerando que estes indivíduos protagonizam o surgimento de uma nova carreira, ao seguirem esta trajetória eles estão desbravando um caminho relativamente desconhecido. Para tanto, precisam atribuir significados, interagir socialmente e mediar discursos. Ao fazerem isso, de acordo Life Design, tem-se como produto o conhecimento e a identidade deste indivíduo.

Os relatos mostraram que, apesar das diferentes realidades individuais existem temas que aparecem em comum. Esses temam podem ser considerados representações identitárias da carreira de empreendedor digital.

Esses retratos não são excludentes, o relato de um mesmo indivíduo pode estar expresso em uma ou mais dessas representações identitárias. Em linhas gerais, podese dizer que o empreendedor digital se apresenta como alguém que prescinde da educação formal; que é patrão de si mesmo e dono do próprio tempo; trabalha de forma incansável; que persegue altos retornos financeiros; que exerce a profissão do "futuro" e que é um profissional do networking. Cada uma dessas construções é discutida, a seguir. 


\title{
4.5.1. O Empreendedor digital como pessoa que prescinde da educação formal
}

Nos relatos obtidos foi possível perceber que alguns empreendedores digitais enxergaram no empreendedorismo digital uma forma de conseguir ser "bem-sucedido" mesmo sem a necessidade da educação formal. Os empreendedores digitais acreditam que a educação formal se baseia em condições controladas e situações previsíveis e constantes, enquanto o meio digital está em constante transformação. A imprevisibilidade e volatilidade desse meio fez com que alguns entrevistados vissem a educação formal como insuficiente ou, ainda, dispensável para o sucesso na área. Laura é uma das entrevistadas que acredita que a educação formal no Brasil é insuficiente para a atuação empreendedora:

\begin{abstract}
"Aqui no Brasil, eu acredito ainda que o estudo ele ainda é muito escasso, né, você não aprende sobre matemática financeira, empreendedorismo, como você ser dono do seu próprio negócio no colégio, nem na faculdade, a faculdade te prepara pra você trabalhar pros outros ainda, você não sai da faculdade sabendo como você vai criar seu próprio negócio, como você vai gerir o seu próprio negócio, você já sai da faculdade pensando o quê? "Ah, preciso arrumar um emprego", você vai procurar empresas pra você trabalhar. Então nem a faculdade prepara pra isso." (Laura)
\end{abstract}

Anderson acredita que a possibilidade de faturar alto sem ter uma educação formal é mais uma virtude do empreendedorismo digital do que um demérito da educação formal:

"E, assim, cara, eu não sou ninguém especial, eu tenho ensino médio completo, eu não tenho curso superior, eu nunca fiz (...) faculdade... E eu acho o empreendedorismo digital fascinante, porque ele é muito democrático, entendeu? Ele te dá possibilidade de uma pessoa que não tenha muito estudo, entre aspas, por exemplo, uma pessoa com ensino fundamental, como eu conheço, pessoas com ensino fundamental, com negócios faturando 30 mil por mês." (Anderson)

Outros entrevistados apontaram que suas insatisfações com o ensino como é dado no Brasil foi fator determinante para que eles se mantivessem no marketing digital. Alguns deles manifestaram que não se viam fazendo faculdade pois não achavam interessante e outros relataram insatisfação com suas aulas na faculdade, dada a forma de exposição e o ritmo dessas. Por isso, esses entrevistados disseram ter percebido na internet uma forma de aprendizado mais otimizada, diretamente ligada com a prática, no ritmo e no tempo em que eles precisavam. Esse aspecto educacional da internet fez com que esses empreendedores digitais atribuíssem à internet um sentido mais amplo: não só a possibilidade de trabalho, mas a possibilidade de aprendizado. As falas de 
Daniel e Carlos mostram que eles acreditam que o aprendizado na internet substitui a educação formal:

"Eu me arrisco a dizer que até as universidades, as faculdades presenciais, esse tipo de coisa, estão muito ameaçadas, assim, pelo digital." (Daniel)

"Eu não preciso fazer uma faculdade pra aprender qualquer coisa. Eu consigo aprender daqui de casa. E isso foi algo que despertou em mim, inclusive despertou uma revolta com a forma de ensino tradicional, o método de ensino, (...) percebi que eu poderia aprender tudo pela internet." (Carlos)

Já para Enzo e Jaqueline, a deficiência no ensino formal apareceu como uma barreira que eles conseguiram superar, ao se tornarem empreendedores digitais bemsucedidos:

"Ah, eu tenho a $7^{a}$ série. Eu gosto de falar isso aí porque algumas pessoas meio que, ah, não fala, mas eu gosto de falar porque dentro da história, né? Mostra que o estudo é sim importante, mas não é tipo um fator principal. Não é o fator principal pra ter sucesso. Pelo menos não na minha área, né?" (Enzo)

"E encontrei aí no empreendedorismo uma forma de superar esse obstáculo aí, que na minha época quem não fazia faculdade estava fora do mercado, né? E hoje a gente prova o contrário." (Jaqueline)

Em outro momento da entrevista Jaqueline comenta de novo a questão de não ter faculdade, o que reforça sua opção por seguir um caminho próprio, diferente do que a sociedade exige, o que contribuiu para forjar sua identidade empreendedora:

"Eu nunca nem cogitei a possibilidade de fazer faculdade, porque não era o que eu queria, eu não me apegava a nada que tinha ali. Eu sabia que eu tinha uma outra coisa, uma outra missão pra fazer, mas eu não sabia exatamente o que que era, mas eu ia encontrar o caminho. E aí eu encontrei, graças a Deus aí, o caminho, no digital, e algo que a gente aprende no digital não se ensina em nenhuma faculdade. Então isso que é o legal, pelo menos até hoje, não ensina. E eu acho que empreendedorismo, e tudo, deveria ser ensinado na escola desde sempre pras pessoas, porque elas são muito educadas a serem empregados, e elas não são educadas a ter uma visão empreendedora". (Jaqueline)

Porém, nem todos os entrevistados desmereceram a educação formal ou falaram dela com indiferença. Hugo, por exemplo, mostrou dar valor à educação formal ao dizer que ela o ajudou a conhecer o mercado digital:

"Eu comecei a fazer faculdade de marketing, eu escolhi essa faculdade pra que eu me aperfeiçoasse, e na faculdade de marketing eu conheci o mercado digital. Logo nos primeiros períodos ali em 2012, 2013, eu comecei a ver como que funcionava o mercado digital e fiz a minha primeira experiência. Mas só em 2014 foi quando eu definitivamente decidi mergulhar de cabeça no mercado digital" (Hugo) 
Argumenta-se que a própria caminhada dentro do empreendedorismo digital e a maneira como eles vão narrando suas experiências com a educação formal vão moldando suas opiniões e fazendo-os adaptar seus discursos e decisões. Essa forma complexa de moldar a própria identidade profissional é explicada por Savickas et al. (2009), que dizem que o indivíduo e seu ecossistema formam uma entidade dinâmica complexa, que resulta de uma auto-organização de adaptação mútua ao longo do tempo. A identidade profissional, assim, é moldada pela auto-organização das múltiplas experiências da vida no dia a dia. Logo, um pressuposto básico do Life Design é reconhecer que o contexto é dinâmico e que as condições em que a carreira se desenvolve são difíceis de serem controladas (SAVICKAS et al., 2009).

\subsubsection{Empreendedor digital como patrão de si mesmo e dono do próprio tempo}

A maioria dos entrevistados ressalta, como grande vantagem e realização do empreendedorismo digital, a liberdade de passar mais tempo com a família e de poder interagir mais com eles ao trabalharem dentro de suas próprias casas, tendo a liberdade de gerir o próprio tempo. Além da autonomia para gerir o próprio tempo, eles enaltecem o fato de poderem trabalhar em qualquer lugar e ter a liberdade geográfica. Assim, a liberdade aparece nas entrevistas como um valor significativo na construção identitária desses empreendedores digitais. As falas abaixo demonstram isso:

"Quando eu trabalhava na indústria lá, eu não podia falar pro meu chefe: "cara, posso dar uma saída aí pra poder entregar o trabalho do meu filho [no colégio]?", jamais eu poderia fazer isso." (Daniel)

"É claro que eu sei que se eu ficar um período sem trabalhar, muito provavelmente eu vou ter que repor depois. Mas isso eu consigo me organizar. Então eu consigo eu mesma me cobrar, não tem aquele negócio de eu preciso trabalhar de segunda a sexta, se eu tiver uma consulta médica, se o meu filho pedir tal coisa, eu não vou conseguir fazer, porque eu tô travada naquele ponto ali. Entendeu? Então essa é a liberdade que eu tenho hoje que só o empreendedorismo digital consegue proporcionar pras pessoas." (Jaqueline)

\subsubsection{Empreendedor digital como trabalhador incansável e resiliente}

Por mais que eles enalteçam a liberdade que tem em trabalhar em casa e poderem gerir o próprio tempo, os entrevistados sabem que o negócio de 
empreendedorismo digital é totalmente dependente do quanto eles trabalham para montar uma estrutura (habilidade de "distribuição", conforme tabela 1 mencionada no referencial teórico). Ou seja, eles precisam espalhar conteúdo em texto, vídeo e áudio no maior número de canais possíveis e trabalhar ao máximo para ampliarem a visualização desses canais por pessoas genuinamente interessadas (leads). Ainda acreditam que precisam trabalhar duro na própria imagem de especialista, de modo a transmitir autoridade naquilo que estão vendendo (habilidade de "venda", conforme a tabela 1).

Além disso, há um consenso entre os empreendedores digitais de que existe a necessidade de ser consistente e persistente em seus trabalhos para ganharem escala, autoridade e para dar tempo de seus conteúdos serem processados pelos algoritmos das diferentes plataformas: Google, Instagram, Youtube, Hotmart, etc. Não obstante, caso parem de criar conteúdo, de se relacionar com clientes e de atualizar conteúdos já existentes, são penalizados pelos algoritmos, que param de espalhar organicamente seus conteúdos. Portanto, eles reiteram a necessidade de serem consistentes para conseguirem se firmar na carreira de empreendedor digital. As falas abaixo mostram o quanto os empreendedores digitais enaltecem seus feitos de forma a validar que superaram esse desafio de serem consistentes:

"É possível ganhar dinheiro na internet. Não é balela. Não é conversa fiada. É possível sim. Só que é preciso trabalhar! É preciso você montar estrutura. Tem toda uma estrutura por trás e isso demora, você tem que trabalhar, você tem que montar, você tem que ralar para lá na frente você falar "hoje eu faturo 7 dígitos, faturo, mas eu trabalhei duro lá trás." (Anderson)

"Eu trabalho aqui na minha casa, do meu filho, eu parei agora pra tomar um cafezinho, meu filho veio aqui me dar um beijo, a gente conversa, eu ajudo ele na escola, mas, cara, eu preciso trabalhar, e eu trabalho muito, muito, várias vezes eu já trabalhei muito mais do que eu trabalhava na indústria. Eu já tive que trabalhar às vezes 10, 12, 15 horas" (Daniel)

"De 2012 até 2016 eu vinha trabalhando... sabe quando faz um pouco e não faz? Eu sempre fui persistente, mas eu não era consistente. Existe uma diferença muito grande nessas palavras. E é vital ser consistente e persistente. Se tiver só um não rola. Se tiver que escolher, escolha a consistência. Quando se é consistente mais resultado se tem." (Carlos)

"Então eu sei que se eu continuar trabalhando, eu consigo ganhar escala, eu consigo ganhar o mundo se eu quiser. Então é só a gente continuar mantendo a consistência e se mantendo atualizado aí nesse mercado." (Jaqueline)

"Olha, só... Eu acho que eu já escrevi mais de 7 mil artigos na internet." (Gabriel)

"A gente trabalha, a gente trabalha duro, a gente cria uma estrutura, a gente acompanha, a gente investe, existe tudo isso." (Jaqueline) 


\title{
4.5.4. Empreendedor digital como detentor de altos retornos financeiros
}

O discurso que exalta o empreendedorismo como sinônimo de crescimento econômico, formador de "heróis globais" e única ordem mundial possível (COSTA et al., 2002) encontra eco nos relatos dos entrevistados quando estes falam sobre os retornos financeiros possíveis. Eles acreditam que as possibilidades de ganhos financeiros são abundantes e retratam seu sucesso neste setor como algo heroico:

\begin{abstract}
"O marketing digital, a internet democratizou o jogo, cara. Antigamente, eu sempre uso essa analogia, antigamente, era você trabalhando para alguém e alguém ficando milionário as custas do seu trabalho, né. Você fazia a mão de obra, você que pagava e o dono da empresa que ganha né. E eu não acho errado, tranquilo. Eu vejo que a internet democratizou isso. Hoje você consegue começar do zero mesmo e ganhar um milhão de reais, faturar um milhão de reais, ganhar dinheiro." (Anderson)

"Eu cheguei em uma posição lá na indústria que o pessoal falava assim: "ah, você está tranquilo aí, trabalhando em um laboratório, em um chãozinho limpo, e ganha um salarião, o pessoal falava, né? Então, assim, (...) era um ótimo salário sim, não posso reclamar, (...), mas financeiramente, (...), principalmente na época de auge aí, eu cheguei a ganhar, faturar, com minha empresa, dentro da minha casa, talvez mais do que o gerente da empresa de onde eu trabalhava, então, financeiramente, eu posso dizer para você que é muito grato, né? Muito gratificante, na verdade, receber um salário desse sem precisar pegar em uma lixadeira, por exemplo. Sem precisar usar EPI, sem precisar usar óculos, capacete, tudo, que eu utilizava, né?" (Daniel)

"A diferença, Luiz Fernando, é que no negócio físico, quem não tem dinheiro de jeito nenhum dificilmente vai alavancar. E no empreendedorismo digital, se você tem personalidade, se você tem conteúdo, se você tem esse jogo ali pras redes sociais, possivelmente você sai do zero e explode, fica milionário. A chance de enriquecer aqui é maior do que lá fora." (Maysa)
\end{abstract}

\subsubsection{Empreendedor digital como o profissional do futuro}

A maioria dos empreendedores digitais mostrou otimismo com relação ao futuro. Ora eles falaram sobre a tendência de digitalização que existe no mundo de hoje, principalmente com a pandemia, ora eles apontaram que o digital está conectado com o que há de novo e tecnológico no mundo. Sendo assim, eles acreditam que serão beneficiados no futuro por estarem adotando essa carreira no presente.

"Eu vou falar um negócio bem enfático pra você, eu acho que daqui a 5 anos seja o vendedor de hot dog, que tem aqueles carrinhos, [seja] algum camelô que trabalha na praia... Se ele não tiver conectado na internet, ele vai sumir do mapa. Não vai existir mais." (Daniel)

"As pessoas ainda não mudaram a mentalidade delas pro digital, né? Se a gente for parar pra pensar, tudo que a gente faz hoje tá ligado à internet, a gente pede comida 
pela internet, né, no iFood, a gente pede um carro, um Uber, a gente programa uma viagem pela internet, a gente aluga uma casa pela internet... Só que as pessoas ainda têm dificuldade em entender que dá pra você também ganhar dinheiro na internet. Né?" (Laura)

Bandera e Passerini (2020) apontaram que empreendedores digitais estão menos preocupados com o futuro do que empreendedores tradicionais. A explicação que eles sugeriram foi que empreendedores digitais tem maior consciência sobre o risco de seus negócios (dada a dinamicidade das tecnologias digitais) e, por isso, a visão de futuro deles é consumida por seu foco na aprendizagem e na tomada de decisão. Já o empreendedor tradicional apresenta uma maior preocupação com o futuro por acreditar que a tecnologia pode representar uma ameaça (BANDERA E PASSERINI, 2020).

Os achados da presente pesquisa não só sugerem que empreendedores digitais estão menos preocupados com o futuro como também são otimistas em relação a ele. Conforme visto nas falas acima, os empreendedores digitais acreditam estarem prontos e preparados para lidar com a tendência de digitalização. Apesar disso, os empreendedores digitais também mostraram que sabem que precisam estar sempre atualizados e estudarem sempre para manterem-se atualizados. A fala de lago ilustra esse ponto.

"Então eu falava, não sei de quê, mas eu quero trabalhar em casa. E quando eu descobri a oportunidade, não precisei nem de incentivo, nem de desincentivo. Eu quis, eu enxerguei futuro, e caí matando em cima. Estudando, estudando, estudando... E eu percebi que eu tenho chance de crescimento, porque do mesmo jeito que o marketing digital é, a vida também. Se você para, você fica desatualizado. Né? Por que que tem muitos idosos que hoje usam o Zoom com tranquilidade, usam o Whatsapp com tranquilidade, mas tem gente que não consegue sequer usar uma máquina de escrever? Porque para. Então enquanto eu tiver me atualizando, como eu tô tentando fazer, eu nunca paro." (lago)

Dado que Savickas (1997) define adaptabilidade de carreira como a prontidão para cooperar com os ajustes imprevisíveis que aparecem nas condições de trabalho, pode-se dizer que os empreendedores digitais se mostraram indivíduos bastante adaptáveis. Aprendizagem constante e tomada de decisão são componentes da adaptação e quando alguém consegue se adaptar a um mundo em mudança, pode rapidamente passar de uma carreira para outra (SAVICKAS, 1997). Em outras palavras, a adaptabilidade de carreira traz flexibilidade individual, bem como acomodação do indivíduo às circunstâncias em mudança (BLUSTEIN et al., 2004). Portanto, outra possível explicação para os empreendedores digitais serem menos preocupados com o futuro (e até mesmo estarem otimistas a ele) está no fato deles se mostrarem indivíduos adaptáveis. Por sua vez, a não exigência de investimentos em estrutura física ou 
estoques os ajuda a serem mais flexíveis e terem maior capacidade de responderem às mudanças do que empreendedores tradicionais.

\subsubsection{Empreendedor digital como profissional do networking}

Apesarem de serem empreendedores que geralmente atuam sozinhos, eles enaltecem a importância do networking. Apontam que, devido à volatilidade e dinâmica do mercado digital, é crucial para sobrevivência nesse meio a troca de experiências e contato com outros empreendedores digitais. Essas parcerias contribuem com a aprendizagem, na resolução de problemas e no aumento das vendas.

"Então, existe uma palavra, não é minha que eu inventei, mas eles falam que: 'networking vale mais do que dinheiro', e é verdade, porque através desse networking, que aí eu comecei a criar novos produtos, né? Fui num evento que eu conheci o Diego, que hoje é o meu parceiro de negócios, um e-book, ele falou, cara, tem um e-book assim e assim, quem sabe a gente cria junto" (Daniel)

"A gente tem grupo no WhatsApp, conversa, troca ideia, tem gente com site grande que está aí bombando, teve gente que o site caiu e eles desistiram, mas foram mexer com outra coisa, teve gente que foi mexer com YouTube, teve gente que... Assim, de todas as áreas... Teve gente que foi mexer com venda, tem loja né de e-commerce (...). Tem gente que lançou curso na área, tem de tudo. Mas eu conheço, assim, a gente tinha um encontro que a gente fazia até uns anos atrás, todo ano a gente se encontrava na agência de um amigo nosso lá no Sul e tal, fazia um encontrão da galera e tal, fazia uma reunião, aí cada um dava uma mini palestra pros outros" (Flávio):

"E quando você tem outras pessoas enxergando o teu negócio de fora, elas acabam te ajudando aí a acertar, traçar uma rota certa aí, pra continuar acelerando, então networking ele é super, super, super importante, mesmo." (Jaqueline):

Portanto, no que tange à construção identitária da carreira do empreendedor digital, foi possível notar que os entrevistados praticamente não usaram os termos "carreira", "desenvolvimento de carreira" ou "planejamento de carreira", suas narrativas vão conectando eventos e acontecimentos de modo dar sentido ao caminho percorrido. Essa forma de narrar suas trajetórias encontra ressonância nas considerações de Savickas et al. (2009, p. 241), quando estes dizem que "uma das principais consequências das inter-relações entre os diferentes domínios da vida é que não mais podemos falar com convicção em "desenvolvimento de carreira" ou "orientação vocacional", ao contrário, devemos vislumbrar "trajetórias de vida", nas quais os indivíduos progressivamente projetam e constroem as suas próprias vidas, incluindo os seus percursos profissionais". Assim, conforme vão aprendendo novos conhecimentos, fazendo networking, se dedicando, obtendo recompensas, se relacionando com colegas 
e clientes e gerenciando seu próprio tempo os empreendedores digitais vão reformulando e remoldando suas identidades de carreira e atribuindo sentido para aquilo que estão se dedicando. A carreira desses indivíduos é, portanto, uma narrativa bem formulada sobre os projetos empreendedores que vem construindo suas vidas. 


\section{Conclusão}

O presente estudo teve por objetivo entender como as carreiras dos empreendedores digitais se constituem de forma objetiva e subjetiva. Para tanto, foram feitas 13 entrevistas em profundidade com indivíduos que ganham a vida e vêm construindo suas carreiras como empreendedores digitais, comercializando produtos ou serviços digitais na internet. A partir da análise dos dados foi possível chegar a algumas conclusões.

Primeiramente é preciso destacar que a pesquisa identificou que os indivíduos que se autodenominam empreendedores digitais em seus perfis nas redes sociais, em geral, são aqueles que se especializam em áreas do marketing digital, como por exemplo marketing de afiliados, criação de infoprodutos, criação de conteúdo, trafego, copywriting, etc. São indivíduos que dedicam seu tempo a ensinarem as habilidades necessárias para ser um empreendedor digital: criação de conteúdo, a distribuição destes e o processo de venda online. Dedicando-se, assim, a promover o empreendedorismo digital e ratificar a retórica empreendedora como heroica, capaz de gerar renda, flexibilidade de tempo e de formas de atuação, desde que se trabalhe com consistência, aprendendo constantemente e fazendo networking. Alguns empreendedores digitais até começaram suas carreiras em nichos mais específicos, como maquiagem, estamparia de roupas e teologia, mas somente ao migrarem para o nicho do marketing digital eles assumem a identidade de empreendedores digital em seus perfis.

Com relação às etapas objetivas de carreira seguidas pelos sujeitos de pesquisa que permitiu que se tornassem empreendedores digitais, vale destacar as quatro mais relevantes, sendo elas: pesquisar no google maneiras de ganhar dinheiro na internet; consumir conteúdo sobre marketing digital; realizar a primeira venda online e participar em congressos ou eventos do setor. Tais marcos objetivos se configuraram como etapas importantes na construção da carreira do empreendedor digital.

Em relação às motivações para se empreender online no Brasil, as entrevistas apontaram quatro principais, sendo elas: insatisfação com trabalhos anteriores; ambição de ganhar mais dinheiro; desejo de empreender, com baixos investimento e risco e; monetização de um hobby. Apesar de não aparecerem diretamente nas falas dos 
entrevistados, o avanço tecnológico e a facilitação de acesso a algumas tecnologias, tais como plataformas de distribuição de conteúdo, aumento do uso de smartphone e internet móvel, aumento do uso de cartão de crédito para compras online, etc. ajudaram a criar um ecossistema digital que contribui para o aumento da percepção de oportunidade para empreender. No que tange à percepção do sucesso, todos acreditam ser bem-sucedidos tanto por terem alcançados metas e objetivos traçados previamente como pela percepção de estarem atuando com mais liberdade de tempo, próximos da família e dedicando seu tempo a construírem algo próprio.

Além disso, os empreendedores digitais se deparam com desafios e barreiras ao tentarem empreender e ao superarem essas dificuldades os empreendedores digitais legitimam suas escolhas de carreira. As principais dificuldades apontadas são: falta de apoio da família e de amigos; preocupações com a saúde mental e física; dificuldades com o uso da tecnologia; medo de acreditarem em promessas vazias e; preocupações com ataques de ódio na internet.

Quanto à construção identitária da carreira do empreendedor digital, alguns grandes temas foram identificados e traduzem em certa medida a identidade psicossocial daqueles que empreendem online. O empreendedor digital se vê, portanto, como um profissional que prescinde da educação formal, podendo ser bem-sucedido independente de escolaridade, numa carreira no qual se é dono do próprio tempo e patrão de si mesmo; com possibilidades de altos ganhos financeiros e escalabilidade, desde que se tenha resiliência e consistência, use do networking e esteja em constante aprendizagem. Além disso, são profissionais que acreditam estar exercendo a atividade que será dominante no futuro próximo.

\subsection{Implicações práticas}

Este estudo representou uma contribuição para os estudos de empreendedorismo digital e sobre novas carreiras, por meio de uma pesquisa social construcionista que se utilizou da teórica de Savickas et al. (2009) conhecida como Life Design que permitiu entender aspectos subjetivos e objetivos que fazem 0 empreendedor digital individual dar sentido, legitimar e construir sua carreira no setor.

Com isso, a presente investigação pode ajudar tanto empreendedores digitais que desejam seguir essa carreira bem como ajudar pesquisadores a entenderem o fenômeno do digital e das ocupações profissionais que surgem na internet. Por meio dos resultados observados, pessoas que almejam empreender podem planejar suas 
carreiras. Ainda, os resultados obtidos indicam que é possível utilizar o Life Design como lente conceitual para desvelar novas carreiras construídas em ambientes dinâmicos.

\subsection{Sugestões de estudos futuros}

Foi observado, ao final das gravações das entrevistas, ao parabenizar o respondente pela narrativa bem estruturada, que muitos deles respondiam ao elogio com comentários de que estão acostumados a narrarem a própria história em palestras, lives ou vídeos gravados.

Segundo Bauer e Gaskell (2003, p.100), "no final da entrevista, quando o gravador estiver desligado, muitas vezes acontecem discussões interessantes na forma de comentários informais. Falar em uma situação descontraída, depois do "show", muitas vezes traz muita luz sobre as informações mais formais dadas durante a narração. Esta informação contextual se mostra, em muitos casos, muito importante para a interpretação dos dados, e pode ser crucial para a interpretação contextual das narrativas do informante." Assim sendo, um estudo a fim de verificar se o fato de os empreendedores digitais terem conhecimento sobre marketing o fazem conhecer conceitos como "jornada do Herói" de Joseph Campbel (1949). Pois, se para Savickas (2012) uma história de carreira bem elaborada é tão importante quanto o que se faz, caso o respondente seja um especialista em criação de narrativas ou criação de mitos, será que isso o ajuda na carreira?

Cochran (1997) demonstrou que criar oportunidades para os indivíduos transformarem os scripts de vítimas da sociedade em roteiros de protagonistas é uma das propriedades mais importantes das narrativas na construção de carreira. Pesquisas que busquem identificar se a narrativa heroica de carreira é determinante para a construção dessas carreiras podem trazer contribuições inovadoras nas pesquisas desse campo.

Além disso, novos estudos são necessários para ajudar a delimitar e a diferenciar a atuação do empreendedor digital, do youtuber e do influenciador digital, dado que as ocupações têm pontos em comum, aclarar os limites entre uma carreira e outra tornase um objeto de estudo relevante.

Por fim, esta investigação mostrou que o empreendedorismo digital está longe de ser um tema totalmente explorado pela academia e que mais estudos são necessários a fim de compreender tanto o ecossistema digital brasileiro quanto à figura do empreendedor digital em si. 


\section{6 Referências Bibliográficas}

ACCENTURE. The promise of digital entrepreneurs: creating 10 million youth jobs in the G20 countries. 2014. Disponível em: < https://citizenentrepreneurs.com/wp-content/uploads/2020/11/Accenture-Promise-Digital-

Entrepreneurs-Creating-10-Million-Youth-Jobs-G20-Countries.pdf >; acesso em 12 de maio de 2021.

ALFREDO, L. H. P. Empreendedorismo: origem e desafios para o Brasil do século XXI, 23 fev. 2011.

ANDERSON, C.; Fabricantes: a nova revolução industrial; Crown Business, 2014.

ANIM-YEBOAH S., Boateng R., AWUNI KOLOG E., OWUSU A., Bedi I. Digital Entrepreneurship in Business Enterprises: A Systematic Review. Lecture Notes in Computer Science, vol 12066. Springer, 2020.

ARNOLD, J. Career concepts in the $21^{\text {st }}$ century. The Psychologist, v. 24, n. 2, p. 106-109, 2011.

ARTHUR, M. B. . The boundaryless career: A new perspective for organizational inquiry. Journal of Organizational Behavior, vol. 15, pp.295-306. 1994.

BANDERA, Cesar; PASSERINI, Katia. Personality traits and the digital entrepreneur: Much of the same thing or a new breed? Journal of the International Council for Small Business, p. 1-25, 2020. DOI: 10.1080/26437015.2020.1724838

BARBOSA, Joseane Alves. A aplicabilidade da tecnologia na pandemia do Novo coronavírus (Covid-19). Revista da faesf, v. 4, 2020.

BLUSTEIN, D. A relational theory of working. Journal of Vocational Behavior, v. 79 , p. 1-17, 2011.

BLUSTEIN, D. L.; SCHULTHEISS, D. E. P.; FLUM, H. Toward a relational perspective of the psychology of careers and working: a social constructionist analysis. Journal of Vocational Behaviour, v. 64, p. 423-440, 2004.

BUJOLD, C. Constructing career through narrative. Journal of Vocational Behavior, v. 64, p. 470-484, 2004.

BRAUN, Virginia; CLARKE, Victoria. Using thematic analysis in psychology. Qualitative research in psychology, vol. 3, no 2, p. 77-101.,2006. 
BROWN, D., Career Choice and Development, São Francisco, CA, Jossey-Bass, 2002.

CAMARGO, S. H. C. R. V.; FARAH, O. E. Gestão empreendedora e intraempreendedora: estudos de casos brasileiros. Ribeirão Preto: Villimpress, 2010.

CARDOSO, Paulo; SAVICKAS, Mark L.; GONÇALVES, Miguel M. Innovative moments in career construction counseling: Proposal for an integrative model. The Career Development Quarterly, vol. 67, no 3, p. 188-204, 2019.

COCHRAN, Larry. Career Counseling: A Narrative Approach. Thousand Oaks, CA: Sage., 1997

COSTA, Alessandra Mello da; BARROS, Denise Franca; MARTINS, Paulo Emílio Matos. A alavanca que move o mundo: o discurso da mídia de negócios sobre o capitalismo empreendedor. Cadernos Ebape. br, v. 10, p. 357-375, 2012.

CRESWELL, John W. A framework for design. Research design: Qualitative, quantitative, and mixed methods approaches, p. 9-11, 2003.

DA SILVA, José Alan Barbosa; SILVA, Murilo Sergio Vieira. Análise da Evolução do Empreendedorismo no Brasil no Período de 2002 a 2016. Revista Estudos e Pesquisas em Administração, 2019, vol. 3, no 2, p. 115-137.

DAVIDSON, Elizabeth; VAAST, Emmanuelle. Digital entrepreneurship and its sociomaterial enactment. In: 2010 43rd Hawaii International Conference on System Sciences. IEEE, p. 1-10, 2010

DHEERIYA, Prakash L. A conceptual framework for describing online entrepreneurship. Journal of Small Business \& Entrepreneurship, vol. 22, no 3, p. 275-283, 2009.

DIX, H. Career Construction Theory and Life Writing, Life Writing, 17:1, 1-7, 2020.

DOLABELA, F. Oficina do empreendedor. Rio de Janeiro: Sextante, 2008.

DRIES, N. The meaning of career success: Avoiding reification through a closer inspection of historical, cultural and ideological contexts. Career Development International, v. 16, n. 4, p. 364-384, 2011.

DRUCKER, P. F. Inovação e Espírito Empreendedor. São Paulo: Pioneira, 1987.

DU, W. SL PAN, N. ZHOU, T. OUYANG From a marketplace of electronics to a digital entrepreneurial ecosystem (DEE): The emergence of a meta-organization in Zhongguancun, China Information System Journal, v. 28 (6), p. 1158 - 1175, 2018.

DY, Angela Martinez; MARLOW, Susan; MARTIN, Lee. A Web of opportunity or the same old story? Women digital entrepreneurs and intersectionality theory. Human Relations, vol. 70, no 3, p. 286-311, 2017. 
EDELMAN, B.; BRANDI, W. Risk, Information, and Incentives in Online Affliate Marketing. Journal of Marketing Research, v. 52, p. 1-12, 2015.

EZZY, D. Qualitative analysis: Practice and innovation. St Leonards. New South Wales: Allen \& Unwin, 2002.

FILION, L. J. Empreendedorismo: empreendedores e proprietários-gerentes de pequenos negócios. Revista de Administração, v. 34, n. 2, p. 5-28, 1999.

GASKELL, G. Entrevistas individuais e grupais. In: BAUER, M. W.; GASKELL, G.Pesquisa qualitativa com texto, imagem e som: um manual prático. Petrópolis: Editora Vozes, 2008.

GIONES, Ferran; BREM, Alexander. Digital technology entrepreneurship: A definition and research agenda. Technology Innovation Management Review, v. 7, n. 5, 2017.

GUNZ, H. P.; HESLIN, P. A. Reconceptualizing career success. Journal of Vocational Behavior, v. 26, p. 105-111, 2005.

GUTHRIE, C.; "The digital factory: a hands-on learning project digital entrepreneurship", Journal of Entrepreneurship Education, Vol. 17 No. 1, pp. 115133, 2014.

HALL, D. T. Protean careers of the 21 st century. The Academy of Management Executive, vol.10, pp. 8-16, 1996.

HISRICH, R. D.; PETERS, M. P.; SHEPHERD, D. A. Empreendedorismo. 7. ed. Porto Alegre: Bookman, 2009.

HOFFMAN, D. NOVAK, T.; How to Acquire customers on the internet. Harvard business review. R00305, mai-jun, 2000.

HOLLAND, J. L. Making vocational choices: A theory of vocational personalities and work environments. Lutz, FL: Psychological Assessment Resources, 1997.

HUANG, Rong. Narrative Medicine in China: how doctors write to understand the profession, Life Writing, 17:1, 89-102, 2020.

KOOIJ, Dorien TAM; BOON, Corine. Perceptions of HR practices, personorganisation fit, and affective commitment: The moderating role of career stage. Human Resource management journal, vol. 28, no 1, p. 61-75, 2018.

KRAUS, Sascha et al. Digital entrepreneurship: a research agenda on new business models for the twenty-first century. International Journal of Entrepreneurial Behavior \& Research, 2018.

KUESTER, E. Konya-Baumbach, MC Schuhmacher Get the show on the road: Goto-market strategies for e-innovations of start-ups Journal of business Research, v. 83 , p. $65-81,2018$. 
LYYTINEN, Kalle; YOO, Youngjin; BOLAND JR, Richard J. Digital product innovation within four classes of innovation networks. Information Systems Journal, v. 26, n. 1, p. 47-75, 2016.

MAINIERO, L. A., \& SULLIVAN, S. E. Kaleidoscope careers: An alternative explanation for the opt-out revolution. The Academy of Management Executive, vol. 19, pp. 106-123, 2005.

MASON, Colin M.; CARTER, Sara; TAGG, Stephen. Invisible businesses: The characteristics of home-based businesses in the United Kingdom. Regional Studies, v. 45, n. 5, p. 625-639, 2011.

MAXIMIANO, A. C. A. Administração para empreendedores: fundamentos da criação e da gestão de novos negócios. São Paulo: Pearson Prentice Hall, 2016.

NAMBISAN, Satish. Digital entrepreneurship: Toward a digital technology perspective of entrepreneurship. Entrepreneurship Theory and Practice, v. 41, n. 6 , p. 1029-1055, 2017.

NASSIF, Vânia Maria Jorge; GHOBRIL, Alexandre Nabil; DO AMARAL, Derly Jardim. Empreendedorismo por necessidade: o desemprego como impulsionador da criação de novos negócios no Brasil. Pensamento \& Realidade, v. 24, n. 1, 2009.

SAVICKAS, M. L. Career adaptability: An integrative construct for life-span, lifespace theory. Career Development Quarterly, v. 45, p. 247-259, 1997.

SAVICKAS, M. L. Career construction: A developmental theory of vocational behavior. In D.Brown (Ed.), Career choice and development, 4th ed., pp. 149- 205;. San Francisco: Jossey-Bass. 2002

SAVICKAS, M. L. et al., Life designing: A paradigm for career construction in the $21^{\text {st }}$ century. Journal of Vocational Behaviour, v. 75, p 239-250, 2009.

SAVICKAS, Mark L. Re-viewing scientific models of career as social constructions. Revista Portuguesa de Pedagogia, p. 33-43, 2010.

SAVICKAS, M. L. Constructing careers: Actors, agents and authors. The Counselling Psychologist. The 2011 Leona Tyler Award Adress, p. 1-15, 2012.

SAVICKAS, Mark. Life-design counseling manual. Mark L. Savickas, 2015.

SHANE, S; VENKATARAMAN, S. The Promise of Enterpreneurship as a Field of Research; The Academy of Management Review, Vol. 25, No. 1, pp. 217-226, 2000.

SIBILIA, Paula. O show do eu: a intimidade como espetáculo. Contraponto Editora, 2020.

SOUZA, Luciana Karine de. Pesquisa com análise qualitativa de dados: conhecendo a Análise Temática. Arquivos Brasileiros de Psicologia, v. 71, n. 2, p. 51-67, 2019. 
STANDING, C. MATTSSON, J. Finja até você fazer: conceituação do modelo de negócios em empreendedorismo digital Journal Strategy Merket., 26 (5), pp. 385 399, 2018.

STEININGER, Dennis M. Linking information systems and entrepreneurship: A review and agenda for IT-associated and digital entrepreneurship research. Information Systems Journal, v. 29, n. 2, p. 363-407, 2019.

SULLIVAN, Sherry E.; BARUCH, Yehuda. Advances in career theory and research: A critical review and agenda for future exploration. Journal of management, vol. 35, no 6, p. 1542-1571, 2009.

SUPER, Donald E. The psychology of careers; an introduction to vocational development. 1957.

SUPER, Donald E. A life-span, life-space approach to career development. Journal of vocational behavior, vol. 16, no 3, p. 282-298, 1980.

VON BRIEL, F. DAVIDSSON, P., RECKER, J. Digital Technologies as External Enablers of New Venture Creation in the IT Hardware Sector, Entrepreneurship Theory and Practice., v. 42 (1), p. $47-69,2018$.

WRIGHT, James Terence Coulter; SILVA, Antonio Thiago Benedete; SPERS, Renata Giovinazzo. O mercado de trabalho no futuro: uma discussão sobre profissões inovadoras, empreendedorismo e tendências para 2020. RAl-Revista de Administração e Inovação, 2010, vol. 7, no 3, p. 174-197.

YOUNG, Ri. A.; COLLIN, A., Ed. Interpreting career: Hermeneutical studies of lives in context. Praeger Publishers/Greenwood Publishing Group, 1992.

YOUNG, R. A.; COLLIN, A. Introduction: Constructivism and social constructionism in the career field. Journal of Vocational Behavior, v. 64, p. 373-388, 2004.

ZAHEER, Hasnain; BREYER, Yvonne; DUMAY, John. Digital entrepreneurship: An interdisciplinary structured literature review and research agenda. Technological Forecasting and Social Change, v. 148, p. 119735, 2019.

ZAPATA, M. E. P.; CASTRO, P. I. H.; MOJICA, I. E. H.; Cambio de paradigma en el Marketing de Afiliados a través de los blogs o redes sociales. Tese de Doutorado. Universidad Nacional Autónoma de Nicaragua, Managua, 2021. 